NBER WORKING PAPER SERIES

\title{
WHAT DO MEASURES OF REAL-TIME CORPORATE SALES TELL US ABOUT EARNINGS SURPRISES AND POST-ANNOUNCEMENT RETURNS?
}

\author{
Kenneth Froot \\ Namho Kang \\ Gideon Ozik \\ Ronnie Sadka \\ Working Paper 22366 \\ http://www.nber.org/papers/w22366 \\ NATIONAL BUREAU OF ECONOMIC RESEARCH \\ 1050 Massachusetts Avenue \\ Cambridge, MA 02138 \\ June 2016
}

We thank an anonymous referee, Daniel Cohen, Robert Korajczyk, Charles-Albert Lehalle (discussant), Xiaoxia Lou, Gil Sadka, and the seminar participants at University of Connecticut, Tel-Aviv University, York University, Cubist Systematic Strategies, State Street Innovation Symposium, and 8th Annual Hedge Fund Research Conference for helpful comments and suggestions. We thank MKT MediaStats, LLC for generously providing data. The views expressed herein are those of the authors and do not necessarily reflect the views of the National Bureau of Economic Research.

NBER working papers are circulated for discussion and comment purposes. They have not been peer-reviewed or been subject to the review by the NBER Board of Directors that accompanies official NBER publications.

(C) 2016 by Kenneth Froot, Namho Kang, Gideon Ozik, and Ronnie Sadka. All rights reserved. Short sections of text, not to exceed two paragraphs, may be quoted without explicit permission provided that full credit, including $(\odot$ notice, is given to the source. 
What Do Measures of Real-time Corporate Sales Tell Us about Earnings Surprises and Post-Announcement Returns?

Kenneth Froot, Namho Kang, Gideon Ozik, and Ronnie Sadka

NBER Working Paper No. 22366

June 2016

JEL No. G0

\begin{abstract}
We develop real-time proxies of retail corporate sales from multiple sources, including $\sim 50$ million mobile devices. These measures contain information from both the earnings quarter ("within quarter") and the period between that quarter's end and the earnings announcement date ("post quarter"). Our within-quarter measure is powerful in explaining quarterly sales growth, revenue surprises, and earnings surprises, generating average excess returns at announcement of $3.4 \%$. However, surprisingly, our post-quarter measure is related negatively to announcement returns, and positively to post-announcement returns. When post-quarter private information is directionally strong, managers, at announcement, provide guidance and use language that points statistically in the opposite direction. This effect is more pronounced when, post-announcement, management insiders trade. We conclude managers do not fully disclose their private information and instead message to shareholders and analysts something of opposite sign. The data suggest they may be motivated in part by subsequent personal stock-trading opportunities.
\end{abstract}

Kenneth Froot

Graduate School of Business

Harvard University

Soldiers Field

Boston, MA 02163

and NBER

kfroot@hbs.edu

Namho Kang

University of Connecticut

Finance Department

namho.kang@business.uconn.edu
Gideon Ozik

EDHEC-Risk Institute

393-400, Promenade des Anglais BP3116

06202 Nice - Cedex 3. France

g_ozik@yahoo.com

Ronnie Sadka

Boston College

Carroll School of Management

B336 Fulton Hall

140 Commonwealth Ave.

Chestnut Hill, MA 02467

ronnie.sadka@bc.edu 


\section{Introduction}

The information asymmetry around earnings announcements has long been near the center of finance and accounting research. At the time of an earnings announcement, managers know not only about their firm's performance over the last accounting quarter ("within quarter") but also about performance since the quarter's end (“post quarter"). The announced numbers - non-discretionary accounting disclosures - of course help remove within-quarter information asymmetries. But these accounting numbers cannot, by definition, eliminate any post-quarter information asymmetries that managers may possess. Additional tools - discretionary accruals, formal guidance and informal call tone - have therefore evolved wherein managers have the opportunity to convey post-quarter information in the current, rather than the next, quarterly announcement. Are these discretionary tools - whose transmitted content is difficult for shareholders to verify - used in the interests of shareholders, as intended? Might they be used instead against shareholders, but in the interests of managers?

This is the question we ask in this paper. We gain some edge in answering it by constructing proxies for managers' within-quarter and post-quarter internal-corporate information around earnings announcements. These proxies are real-time measures of sales activity covering both within- and postquarter periods, right up until the announcement date, typically 4-6 weeks after quarter end. The proxies are constructed from multiple big-data sources that provide real-time information about consumer sales at US retailers.

To construct our firm-level real-time corporate sales (RTCS) index, we estimate the amount of consumer activity at retail stores utilizing proprietary data sources. An example would be the data we collect from approximately 50 million mobile phones, as well as tablets and desktops, pertaining 
to consumer activity at large US retailers. ${ }^{1}$ We focus on US retail firms whose main revenue source comes from their own retail stores. The within-quarter RTCS index for a given firm in quarter $t$ is obtained from the quarterly growth rate of consumer activity - defined to be a data event associated with consumer intention to visit a particular retail store - by taking the log difference between the number of events aggregated over quarter $t$ and the quarterly average of the number of events aggregated over quarters $t-1$ to $t-4$.

The innovation here is twofold. First, we are capturing firm-specific real-time economic activity that tracks consumer activity. Our measure is distinct from social media variables (e.g., Chen, De, Hu, and Hwang, 2015) because it seeks to measure actual consumer activity, rather than derived opinions or sentiment and is therefore more tightly linked to underlying sales fundamentals. Second, because a firm's managers likely have access to up-to-date information on the firm's operations, our within- and post-quarter RTCS indexes are, at the time of announcement, useful proxies for managers' private information, not available to the public.

We first demonstrate that our within-quarter RTCS measure is - as hoped - related to previously-unannounced within-quarter fundamentals. Specifically, we find that within-quarter RTCS significantly predicts current-period revenue growth, announcement surprises and analyst forecast errors. For example, the $\mathrm{R}^{2}$ from a regression of quarterly revenue growth on our within-quarter RTCS is 39\%. Also, the average announcement excess return for stocks in the highest quintile of withinquarter RTCS is $2.14 \%$, while that for stocks in the lowest quintile is $-1.26 \%$, resulting in an economically significant return differential of $3.4 \%$ for the five-day period around earnings announcement dates. Our information is therefore strongly correlated with previously unannounced

\footnotetext{
1 There are many anecdotes that sophisticated investors have increased efforts to achieve an informational edge by analyzing unique data to predict firms' fundamental activities. For example, a UBS analyst was reported to have purchased satellite images of Walmart's parking lots to estimate business activity ahead of the release of quarterly earnings (Ozik and Sadka, 2013).
} 
within-quarter sales. These predictions are not really surprising, but they do confirm that our novel informational measures are potent.

Next, we focus on post-quarter RTCS. We ask about its relationship with post-announcement returns, discretionary accruals, announced "guidance” forecasts, conference-call tone, and managers' private discretionary trades in the post-announcement trading window. The organizing concept is what we call the Timely Disclosure Hypothesis, i.e., the notion that managers release through available channels all of their private post-quarter information at announcement. Our first and most important test of this null attempts to detect predictability in post-announcement returns using post-quarter RTCS. If managers disclose all of their private information as measured by post-quarter RTCS, we should observe none. Second, such timely disclosure implies that post-quarter RTCS is positively related to the announcement return over and above the effects of within-quarter information, including within-quarter RTCS.

The natural alternative to Timely Disclosure is the hypothesis we call 'Leaning Against the Wind' (LAW). Under this alternative, managers use discretionary channels to understate, even reverse, the private information contained in post-quarter RTCS. That is, managers don't disclose their private signal, withholding some of the surprise for the future. They thereby induce opposite-sign predictable components in announcement and post-announcement returns. ${ }^{2}$ Thus, under the LAW alternative, we should find that post-quarter RTCS is: $\imath$ ) correlated negatively with the announcement returns over what we would have forecast using within-quarter RTCS and other controls; and ii) correlated positively with post-announcement returns.

\footnotetext{
2 There is already some evidence in the literature of a related effect, in which managers appear to behave asymmetrically when they fail Timely Disclosure. (Our hypothesis is symmetric.) Specifically they withhold by delaying bad news and withhold less -- more fully announcing -- good news. See Kothari, Shu, and Wysocki (2008) and Roychowdhury and Sletten (2012).
} 
We can confirm and potentially strengthen these results by also examining the attributes of announcements. That is, if there is a LAW understatement or reversal of private information, we should see it in direct measures of discretionary disclosures. For us, these disclosure channels are three: discretionary accruals; guidance (in this case, managers" "bundled forecasts"); and conference call tone, measured through natural language processing modules. If we reject Timely Disclosure in favor of the LAW alternative, these should each, all else equal, be negatively related to post-quarter RTCS. Naturally if we find a positive correlations between the measures of disclosures and post-quarter RTCS, then we cannot reject the Timely Disclosure null.

Our results attest to strong power in favor of the LAW alternative, however. First we look at stock returns themselves. We find that post-quarter RTCS strongly positively predicts postannouncement returns. This same conclusion holds using excess announcement returns, which, over and above other effects (e.g., within-quarter RTCS, earnings forecast and surprise, etc.), are negatively correlated with post-quarter RTCS. Thus, the basic stock return data show managers understate their post-quarter private information.

Second, we look at the three direct measures of discretionary disclosure. Do these provide evidence, independent of that from stock return data, that managers don't fully disclose and instead lean against the wind of their private signals?

First, we examine discretionary accruals. The LAW alternative predicts that discretionary accruals appear suppressed when post-quarter RTCS is high - a negative correlation. Our empirical tests do not show a strong relation between discretionary accruals and post-quarter RTCS, so we cannot reject Timely Disclosure in favor of LAW alternative based on the accruals of all firms. However, we find evidence of a negative relationship across a smaller group of firms where we might expect this test to have greater power: i.e., for firms that marginally miss analyst consensus forecasts. 
The managers of these firms may not have so much at stake vis a vis current earnings and so may reduce discretionary accruals to lower market expectations in the presence of positive post-quarter sales performance.

Second, we ask whether management forecasts or "guidance" issued around earnings announcement dates (often called "bundled" forecasts) reject Timely Disclosure, and, if so, if they do so in favor of LAW. The evidence here is similar, but considerably stronger: bundled forecasts are systematically negatively related to post-quarter RTCS. The probability of realized future earnings (or revenue) exceeding bundled forecasts is positively and significantly associated with post-quarter RTCS. As the LAW alternative would predict, managers issue more pessimistic (optimistic) forecasts - in this case, guidance -- in the presence of more positive (negative) post-quarter sales information.

Finally, we examine managerial tone in announcement conference calls. Specifically, we generate sentiment scores measuring managerial tone from managers' speech using conference call transcripts. Managerial tone is defined as the ratio of the number of positive words to the sum of the number of positive and negative words, where the list of positive and negative words is from Loughran and McDonald (2011). Just as with discretionary accruals and bundled forecasts, we test sentiment scores against post-quarter RTCS. And as above, we find that call sentiment is significantly and negatively related to post-quarter RTCS. This holds with and without controls alike.

Summarizing thus far, the conclusions we derive about managerial behavior from post-quarter RTCS are the same whether we look to announcement and post-announcement returns or whether we look to direct channels of managerial discretion - discretionary accruals, guidance, and conferencecall tone - offered at announcement. All these data sources point toward rejection of Timely Disclosure in favor of the LAW alternative. 
The next logical question is why. Why would managers consistently across channels, choose to understate or even reverse their private signal, leading the information withheld to leak out only slowly, post-announcement?

Clearly, if managers at announcement obscure fundamental information for a quarter, they enjoy a transitory informational asymmetry versus analysts and the market. This improves their postannouncement trade opportunities. We note that managers could in principal also induce equal-sized asymmetries by magnifying - i.e., overstating - their private signals instead of reversing them. However, managers' observed preference - to 'lean against the wind', rather than 'run with the wind' - makes sense in the presence of imperfect credibility. To see this, suppose the private signal is an 1standard-deviation good news. A 2-standard-deviation downward distortion would have managers conveying 1-standard-deviation bad news, while an equivalent 2-standard-deviation upward distortion would require conveying 3-standard-deviation good news. If the market did a complete statistical analysis, these same-sized distortions would reduce credibility equally. However, in the absence of more complete sampling information, magnification sounds hyperbolic. Reversal announcements can be of the same magnitude as true signals, yet provide managers substantial distortionary effects.

Thus our rejection of Timely Disclosure suggests reversal in discretionary announcements. Are insiders' trades after earnings announcements consistent with this? While there are relatively few such insider trades in our sample, we find that the negative relation between post-quarter RTCS and announcement return is stronger when insiders subsequently purchase their firms' shares. We also show that the positive predictability of post-quarter RTCS for announcement returns is even stronger in the presence of subsequent insider purchases.

The rest of this paper is organized as follow. In the next section, we review related literature. Section 2 describes our methodology and the main variable, RTCS. Section 3 demonstrates the 
predictability of RTCS for fundamentals as well as announcement returns. In Section 4, we study returns around earnings announcement dates and the information contained in post-quarter RTCS. In Section 5, we examine the mechanisms through which managers can potentially manipulate the market's expectation as well as their post-announcement trades. In Section 6, we provide our concluding remarks.

\section{Related Literature}

Our paper adds to the literature on managers' asymmetric incentives to disclose good news versus bad news. In general, the literature has shown that bad news tends to be delayed and good news tends to be accelerated. For example, Kothari, Shu, and Wysocki (2008) show that managers delay the release of bad news up to a certain threshold, but release good news immediately. Roychowdhury and Sletten (2012) discuss the earnings reporting process as a mechanism that forces managers to disclose bad news that they otherwise have incentives to withhold. Graham, Harvey, and Rajgopal (2005) document that some CFOs claim that they delay bad news disclosures in the hope that the firm's status will improve. However, there are opposing incentives to release bad news early. For example, Skinner (1994, 1997) and Baginski, Hassell, and Kimbrough (2002) show that litigation risk can motivate managers to quickly reveal bad news. Contrary to the discussion on bad news disclosure, only a few papers study managerial incentives to delay the disclosure of good news. Yermack (1997) (see also Aboody and Kasznik, 2000) shows that CEOs receive option awards shortly before favorable news, implying a delay of good news. Our paper contributes to the literature, showing that managers' departures from the Timely Disclosure Hypothesis may be sensitive to post-quarter private information held by managers at announcement and that managers may act through their stock trading to benefit from these departures. 
Our paper also touches on the literature on insider trading. Rogers (2008) shows that managers provide high-quality disclosures before selling shares and low-quality disclosure prior to purchasing them. Piotroski and Roulstone (2005) show that insider trades are positively related to firms' future earnings performance and inversely related to recent returns, indicating that insiders possess superior information and that this information is most valuable when the market has it wrong. Jenter (2005) also finds that top managers act to express contrarian views on firm value. Roychowdhury and Sletten (2012) provide evidence that managers delay the disclosure of bad news when they are net sellers. Our findings are generally consistent with these views, but further show that insiders may be able to manage the market's impression through their announcements in ways that make their private information at announcement more valuable to their personal trading.

Finally, this paper is related to a growing literature that uses textual analysis to understand financial markets (Tetlock (2007), Tetlock, Saar-Tsechansky, and Macskassy (2008), Loughran and McDonald (2011)). Mayew and Venkatachalam (2012) use vocal emotion analysis software to show that managerial vocal cues contain useful information on firms' fundamentals. Chen, De, Hu, and Hwang (2015) study Seeking Alpha, a popular financial blog, and find that positive sentiment predicts earnings announcements and future stock returns. Druz, Petzev, Wagner, and Zeckhauser (2016) show that conference call tone predict future earnings and uncertainty. Bartov, Faurel, and Mohanram (2015) use the Tweeter feed to extract aggregate sentiment before earnings announcements. Our paper studies the textual tone of managerial conference calls to see if it conforms to the Timely Disclosure Hypothesis. 


\section{Methodology and the Main Variable}

\subsection{Research Questions and Methodology}

We construct the main proxy for real-time corporate sales, which we call "RTCS," to mimic firms' sales systems, but using the proprietary outside data sources described below. In Section 3, we show that RTCS indeed contains superior information and predicts revenue surprises, earnings surprises, and returns around earnings announcements.

Once we establish the informativeness of RTCS, we ask how managers' private information affects their incentives for disclosure and their trading behavior. Our analysis centers on earnings announcement dates. Earnings announcements are events during which operating results of the previous quarter are disclosed and discussed. Investors naturally attempt to process the implications of this new information for future operating performance. Our null hypothesis - the Timely Disclosure Hypothesis - states that managers truthfully communicate their private information pertaining to the following quarters to reduce information asymmetry proxied by post-quarter RTCS. Our alternative hypothesis is that managers conceal or even alter the contents of their private information for various reasons discussed below.

Figure 1 helps to explain how we construct our main variables to examine the relation between managerial private information and reported earnings. The figure plots the time line around the earnings announcement date for Quarter t. The post-quarter period is defined as the time period between the beginning of the fiscal-quarter $t+1$ and the announcement date of quarter- $t$ earnings. We denote within-quarter sales information measured by RTCS for fiscal quarter $t$ as $\mathrm{WQS}_{\mathrm{t}}$, and postquarter sales information measured by RTCS for the post-quarter period as PQS . 
The primary source of private information is probably a manager's superior ability to forecast revenues and earnings. Based on the demonstrated strong ability of WQS to proxy for within-quarter variables, we find it reasonable to assume that PQS proxies analogously for post-quarter business activities and that it is therefore correlated with managers' performance expectations for quarter $t+1$.

First, we examine whether managers convey their private information in a timely manner. If managers inform market participants of their private information at announcement dates, then, according to the Timely Disclosure Hypothesis, the post-quarter RTCS should not be associated with post-announcement returns. We therefore investigate the relation between PQS and the postearnings-announcement returns.

Next, we ask about whether managers simply withhold private information, or whether they influence its interpretation in some way. Delaying the announcement of good news contained in PQS, would of course result in a positive correlation between PQS and post-announcement returns, as stated above. However manager go farther. Rather than simply delay the release of private information, they may seek to distort it, in particular by leaning against, rather than remaining silent about, their private information. Of course such behavior strengthens the positive correlation we will find between PQS and post-announcement returns. But, in addition, it induces a dispositive correlation between current announcement returns and PQS. That is, if managers in possession of more positive private information alter negatively accruals, bundled forecasts and conference call tone, then they are actively leaning against their private information and creating a more negative announcement return. If this is the case, we will observe that PQS is negatively correlated with announcement returns and with these measures of announcement disclosures.

Next, and more importantly, we robustify by testing three completely different channels of communication through which managers may convey their private information at announcement to 
market participants. Specifically managers can use discretionary accruals (Demski, 1998), guidance issued at announcement (e.g., "bundled" forecasts), and conference call tone to convey their private information through their reporting discretion. We test the Time Disclosure Hypothesis on each of these.

Finally, having found evidence of negative correlations of PQS with announcement returns and with measures of announcement disclosures, we then - naturally - ask whether managers' trading patterns are associated with their announcement disclosures. If managers possess a positive private signal but can nevertheless convey to investors a negative estimate of that signal, announcement returns are reduced and post-announcement returns are predictably increased. The benefits of postannouncement purchases of stock are then greater. Indeed, if managers are aware ahead of time of their ability to benefit from these circumstances, then the negative correlation between PQS and announcement returns would be stronger when insider purchases take place. The positive correlation of PQS with post-announcement returns would also be stronger if insider purchases occur, postannouncements. Therefore, we examine the relation among PQS, insider trades after announcement dates, and price movements during and after announcement dates.

\subsection{Real-Time Corporate Sales Index}

We obtain measures of real-time consumer activity from MKT MEDIASTATS, LLC. The data is collected from millions of consumer devices, including approximately 350 million mobile phones, tablets, as well as desktop computers worldwide, of which approximately 50 million are US based. The data only include large big-box retailers whose main revenue source comes from their physical retail stores, and does not include online shops or other types of retailers, such as telecommunication companies or restaurants. Therefore, the sample consists of 50 US big-box retail firms. 
Table 1 provides the list of firms in the sample, their ticker symbols and US based revenues as of 2014. There are 29 firms in the sample included in the top 100 US retailers by National Retail Federation (NRF). NRF data include private firms, online retailers, restaurants, and telecommunication companies, as well as big-box retailers. Total US 2014 revenue of sample firms is $\$ 1.2$ trillion and average (median) revenue is $\$ 24.4$ billion ( $\$ 7.3$ billion). Total revenue of sample firms is about $64 \%$ of total revenue of the NRF 100 . Sample firms cover $77 \%$ of total revenue of the pure retailers of top NRF 100 firms, when we exclude non-pure retailers, such as restaurants and telecommunications, from the list.

Our consumer activity data records specific types of events. Specifically, an individual event is defined by what appears to be a consumer's intention to visit a particular retail store. These events are counted and aggregated per retailer each week. For example, a search for driving directions to a geographical location of a Walmart is counted toward Walmart's consumer activity for the week. Some retailers have multiple brand name stores. For example, GAP has several brand name stores, including Gap, Banana Republic, Old Navy, Piperlime, Athleta and INTERMIX. Thus, total events for GAP aggregate across these brand name stores.

The real-time corporate sales index (RTCS) is derived using weekly consumer activity data described above aggregated to the firm level. First, individual events are aggregated over a quarter per firm. We define within-quarter RTCS (WQS) for quarter $t$ and firm $i$ using the quarterly growth rate of firm is events over the previously four quarters, taking log differences between the number of events aggregated over the quarter $t$ and the quarterly average of the number of events aggregated over quarters $t-1$ to $t-4$.

Post-quarter RTCS (PQS) is measured in a similar fashion. First, we aggregate individual events during the post-quarter period and express in full-quarterly growth units. Specifically, we 
multiply the aggregated consumer events by the number of weeks in quarter $t+1$ and divide the product by the number of weeks in the post-quarter period to reach the estimated quarterly number for $t+1$. PQS is then, analogously to WQS, the log difference of the estimated number of events for the quarter $t+1$ and the quarterly average of the number of events aggregated over quarter $t$ to quarter $t-3$.

Figure 2 illustrates an example of one of the data sources on consumer activities that are used to construct real-time corporate sales index. The first and second panels provide daily time series of individual events pertaining to GAP and Target Corporation over the period of Dec. 2012 to Nov. 2013, while the third panel shows the time series of events for a larger sample derived from data extracted from Android mobile devices in the United States. The time series are normalized by scaling the highest value of the daily activities during the time period. The figure shows that observed patterns are correlated with consumption. For example, all three panels share a similar pattern, displaying higher levels of activity during holiday seasons and spikes in volumes during weekends. The mid-year spike in GAP coincides with a mid-year sale event.

\subsection{Variable Definitions and Summary Statistics}

We use CRSP to obtain stock market variables, including stock returns, prices, and number of shares outstanding for the firms in our sample. IBES detail history file is used to obtain analyst forecasts and earnings announcement dates. And, firms' financial statements are obtained from Compustat.

Table 2 shows the summary statistics of main variables. The variables are defined as follow; The quarterly revenue growth for firm $i$ as of fiscal quarter $t$ is calculated as $\mathrm{S}_{\mathrm{i}, \mathrm{t}} / \mathrm{S}_{\mathrm{i}, \mathrm{t}-1}-1$, where $\mathrm{S}_{\mathrm{i}, \mathrm{t}}$ is the quarterly revenue as of fiscal quarter $t$ for firm $i$; To estimate the standardized unexpected revenue (SUR), we assume that the revenue follows a seasonal random walk with a drift. Specifically, the SUR 
for stock $i$ in quarter $t$ is defined as $\left[\left(\mathrm{S}_{\mathrm{i}, \mathrm{t}}-\mathrm{S}_{\mathrm{i}, \mathrm{t}-\mathrm{4}}\right)-\mathrm{r}_{\mathrm{i}, \mathrm{t}}\right] / \sigma_{\mathrm{i}, \mathrm{t}}$ where $\sigma_{\mathrm{i}, \mathrm{t}}$ and $\mathrm{r}_{\mathrm{i}, \mathrm{t}}$ are the standard deviation and average, respectively, of $\left(\mathrm{S}_{\mathrm{i}, \mathrm{t}}-\mathrm{S}_{\mathrm{i}, \mathrm{t}-4}\right)$ over the preceding eight quarters; The standardized unexpected earnings (SUE) is estimated as $\left(\mathrm{AE}_{\mathrm{i}, \mathrm{t}}-\mathrm{FE}_{\mathrm{i}, \mathrm{t}}\right) / \mathrm{P}_{\mathrm{i}, \mathrm{t}}$, where $\mathrm{AE}_{\mathrm{i}, \mathrm{t}}$ is quarterly earnings per share announced for quarter $t$ of stock $i, \mathrm{FE}_{\mathrm{i}, \mathrm{t}}$ is the mean of analysts' forecasted $\mathrm{EPS}$, and $\mathrm{P}_{\mathrm{i}, \mathrm{t}}$ is quarter-end price; The announcement return is calculated as the return in excess over the market during the period of one day before the earnings announcement date and three days after the announcement date; The postearnings-announcement return (PAR) is the return of each firm in excess over the market for the period beginning on four days after the announcement dates for fiscal quarter- $t$ earnings and ending on 60 days after the announcement dates.

Panel A shows the descriptive statistics of main variables, including the mean and standard deviations as well as quartiles of each variable. The within-quarter RTCS (WQS) has slightly higher average, median, and standard deviation compared to revenue growth. The mean (median) of WQS is 0.034 (0.024) with the standard deviation of 0.316 , while the revenue growth has the mean (median) of $0.027(0.015)$ and standard deviation of 0.209 . Announcement returns are positive on average, having the mean of $0.7 \%$ and the median of $0.3 \%$. The average PAR is also slightly positive being $0.2 \%$, but the median of the post-earnings-announcement returns has a negative value of $-0.2 \%$.

Panel B reports correlations of the variables. The upper right corner of Panel B reports Pearson correlations and the lower left corner of the table provides Spearman's rank correlations. The WQS has significant and positive correlations with revenue growth, SUR, SUE, and announcement return. The correlation between WQS and PAR is significantly positive at $10 \%$ level using Pearson correlation and 1\% using Spearman's rank correlation. As expected, revenue growth and SUR have significantly positive correlations with SUE, and announcement returns, and a positive correlation with PAR, implying that revenue growth and surprises are important sources for SUE and announcement returns, as well as for post-earnings-announcement returns. 


\section{Predictability of RTCS}

In this section, we examine the informativeness of RTCS with respect to firms' fundamentals. We create RTCS with the intention of estimating customer activities at US retailers. We assume that this measure is directly related with the real consumption in retail stores, which in turn is correlated with firms' sales and earnings. Therefore, we test the validity of RTCS as a predictor of revenue and earnings as well as announcement returns around quarterly earnings announcements.

\subsection{Sales and Earnings}

Table 3 shows the predictive power of RTCS for revenue growth and surprises. Panel A shows the regressions of the quarterly revenue growth on the quarterly growth of consumer activities, where a consumer activity is a consumer's intention to visit a particular retail store as defined in Section 2. Panel A uses the quarterly growth of consumer activities as the independent variable, instead of the within-quarter RTCS (WQS), to map with the time horizon of the dependent variable which is the revenue growth of quarter $t$ from quarter $t-1$. Thus, the purpose of analysis in Panel A is to test whether the consumer activity data utilized to calculate WQS is informative in predicting firms' revenue.

Models (1) to (4) show the results of pooled time-series cross-sectional regressions. For Models (2) to (4), we include time (year-quarter) fixed effect, firm fixed effect, and both time and firm fixed effect. Model (5) shows the result of Fama-MacBeth regression. Specifically, each quarter, we estimate cross-sectional regressions of revenue growth on the quarterly growth rate of consumer activities. Then, we calculate the time-series average of coefficients of the regressions and its $t$-value. For Models (1) to (4), we report the adjusted $\mathrm{R}^{2}$, while the average $\mathrm{R}^{2}$ is reported for Model (5). The 
sample consists of firm-quarters of US retailers with fiscal quarter ending between March 2009 and July 2014.

Panel A shows a strong predictability of our consumer activity data for revenue growth. The simple regression (Model 1) shows that $\mathrm{R}^{2}$ of the regression is $39 \%$. The coefficient is 0.4 with a significant $t$-value of 24 , implying that $1 \%$ increase in consumer activities is associated with $0.4 \%$ increase in revenue. The predictability is robust to firm and time fixed effects, as well as FamaMacBeth regression in Model (5). The magnitude of coefficient is somewhat smaller being 0.29 in Model (5). However, the $t$-value is significant at 8.62 and the average $\mathrm{R}^{2}$ of each cross-sectional regression is $23 \%$.

Figure 3 shows the results of Table 3 graphically. The figure scatter-plots revenue growth on the growth of consumer activities. The vertical axis is the quarterly revenue growth and the horizontal axis is the consumer-activity growth. The red line is the predicted value of revenue growth using consumer activities. As in Table 3, the slope of the fitted line is less than one, which implies that not all traffic to stores leads to actual consumption. However, the scatter plot shows a strong correlation, confirming the predictability of revenue growth using the consumer activity data.

In Panel B, we study revenue surprises using the within-quarter measure of RTCS (WQS), defined in Section 2, as the explanatory variable. Specifically, Panel B reports the results of regressions of the SUR on WQS, using the same specifications as in Panel A. Panel B demonstrates that WQS has a strong predictability for revenue surprises, and the predictability is robust to firm and time fixed effects. For example, the specification with both time and firm fixed effect (Model 4) yields a coefficient of 0.7 on WQS with a $t$-value of 2.92. Fama-MacBeth regression model provides very similar results, implying that the predictability of WQS is unlikely due to specific periods in time or unobserved firm characteristics. 
Now, we examine the relation between earnings and WQS. Table 4 shows that WQS has a predictive power for earnings beyond revenue surprises. Model (1) shows the result of simple regression of SUE on WQS. The WQS enters the model with a significant and positive coefficient with $t$-value of 2.37. In Model (2), we analyze the effect of revenue surprises on earnings surprises. Jagadeesh and Livnat (2006) shows that stock price reaction on the earnings announcement date and drift after announcements is significantly related to revenue surprises. Ertimur, Livnat, and Martikainen (2003) study different sources of earnings surprises and find that investors value revenue surprises more highly than expense surprises. Consistent with these studies, we find that SUR is highly correlated with SUE, implying SUR is important source of earnings surprises.

Model (3) includes both WQS and SUR. Although the magnitude of both SUR and WQS become slightly smaller than previous specifications, both variables remain statistically significant. Model (4) controls the lag of SUE to address the persistence of SUE (Bernard and Thomas 1989, 1990, Arbarnell and Bernard, 1992). The lagged SUE has an insignificant coefficient, implying the persistence of SUE is not observed in our sample. In addition, the inclusion of the lag of SUE does not affect WQS and SUR, both of which remain statistically significant.

Models (5) to (8) examine whether time-specific effects or firm-specific heterogeneity drive the results. Specifically, we add time and firm fixed effects or use Fama-MacBeth method. With the exception of the Fama-McBeth regression which yields a positive but insignificant coefficient on WQS, the predictability of WQS for earnings surprises is robust. For example, WQS enters Model (7) - a regression of SUE on WQS, SUR and time and firm fixed effects - with a coefficient of 0.172 and a $t$-value of 2. Interestingly, the lagged SUE has the opposite signs for different specifications, implying that the persistence of SUE is not robust in our sample. Overall, the analysis in Table 4 demonstrates the predictability of earnings surprises using WQS. 


\subsection{Return Predictability}

Now, we turn our attention to announcement returns. Table 5 examines the return predictability of WQS around earnings announcements. We use a five-day event window around earnings announcement beginning one day prior to the announcement date and ending three days afterward. Berkman and Troung (2009) document that the proportion of Russell 3000 firms which make afterhours earnings announcements is more than $40 \%$. For after-hours announcements, earnings related price changes are not observed on day 0 but observed on day one. In addition, forecasts for following quarters are usually announced within one-trading day, thus a longer event window help to capture the complete reaction of the market to the announcement. ${ }^{3}$

Panel A shows the average announcement returns during the event window by quintiles of WQS. Returns are calculated in excess of the market returns of the corresponding periods. Quintiles of WQS are calculated using the following process. At the end of month $t$, we group the firms that have fiscal quarter ending during the three-month rolling period starting month $t$ - 2 and ending $t$. Using the group of firms, we rank firms based on WQS to obtain quintile cutoff values. Then, we use the quintile cutoff values to assign quintile ranks for the firms that have fiscal quarter ending in month $t$. Thus, each quintile can have a different number of events. We follow this process to make sure that we use all the sample firms in ranking them in quintiles. Different ways to assign quintile scores - for example, each month $t$, rank firms only using firms that have fiscal quarter end at $t$ - does not change our results.

Panel A shows the significant relation between WQS and announcement returns. The average announcement returns are monotonic with the quintiles of WQS. The average return around the earnings announcements of firms in the lowest quintile is negative $1.26 \%$, which is statistically

${ }^{3}$ Choosing different event windows does not alter the inference. 
significant at 10\% level. On the contrary, the average announcement returns of quintile 4 and 5 are $1.67 \%$ and $2.14 \%$, respectively, and both are statistically significant at $1 \%$ level. The last column of the panel shows the result of hypothesis testing for the mean difference between highest and lowest quintiles. The difference between the highest and the lowest quintile is economically significant $3.40 \%$ for the five-day holding period, and is also statistically significant with $t$-value of 3.43 .

In Panel B, we take a regression approach to address the concern whether specific time period or small group of firm drive the return predictability. Thus, we estimate various regression models of announcement returns on WQS. Models (1) to (4) show the results of pooled regressions, while Model (5) uses the method of Fama-MacBeth. For Models (1) to (4), we report the adjusted $\mathrm{R}^{2}$, while the average $\mathrm{R}^{2}$ is reported for Model (5).

Consistent with Panel A, results in Panel B show there is a significant relation between announcement returns and WQS. In Model (1), WQS enters the regression with a significant positive coefficient of 0.035 and a $t$-value of 3.86 . This significant predictability of WQS for announcement returns is robust to time (year-quarter), firm, and both time and firm fixed effects. The Fama-MacBeth regression model also gives consistent results. The magnitudes of the coefficients on WQS from all the specifications are very similar around 0.035 . This is economically significant, implying that a one standard deviation increase in WQS is related with about a 1.1\% increase in announcement return.

The informativeness of WQS in predicting announcement returns is apparent in Figure 4. The figure plots the average buy-and-hold returns during the event window from 10 days prior to the earnings announcement date (day 0) to 10 days afterward. Returns are calculated in excess of the market returns of corresponding periods. The first panel shows the average buy-and-hold return of firms in the lowest quintile, while the second panel shows the results of the highest quintile. The graph shows the power of WQS as a predictor of earnings surprises. The pattern of event time returns for 
the firms in the lowest quintile is strikingly contrasting to that of the firms in the highest quintile. There is a statistically significant negative jump around announcement dates for the firms in the lowest quintile, while there is a positive jump around announcements for the firms in quintile five. This result reinforces the predictive power of WQS for earnings surprises and announcement returns.

\section{Private Information and Corporate Disclosure}

Previously, we demonstrate that the within-quarter RTCS (WQS) contains important information on firms' fundamentals, thus has strong predictive power for earnings surprises and announcement returns. In this section, we use post-quarter RTCS (PQS) as a proxy for managers' private information and study how it affects managers' incentives for disclosure timing and contents. The strong predictability of WQS for firms' fundamentals justify the use of PQS as a proxy for managers' expectation for the following quarter. And, the reliability of PQS as proxy for managers' private information provides a unique opportunity for studying managerial behavior toward corporate disclosure.

\subsection{Post-Earnings-Announcement Returns and Private Information}

We examine how managements' private information affects managers' decision on disclosure timing. We use the RTCS for the post-quarter period - the period beginning fiscal-quarter $t+1$ and ending prior to the announcement date for quarter-t earnings - as a proxy for the management's expectation of the quarter $t+1$ earnings and revenue. As described in Figure 1, we denote this post-quarter RTCS as PQS. Managers of a firm have private information due to their superior ability to forecast revenues and earnings. One of the main sources of their superior forecasting ability is the access to operating systems which provide real-time information on the firm's fundamental activities. And, the 
information on business activities during the post-quarter period is likely to be an important source of managers' forecast for quarter $t+1$. Based on the predictability of WQS, it is reasonable to assume that PQS reliably measures the business activities during this post-quarter period, therefore is correlated with managers' expectation for quarter $t+1$.

Do managers convey their private information at the time of earnings announcement upon seeing good post-quarter sales? The literature has documented managerial incentives to withhold bad news while releasing good news immediately. Thus, we study whether managers release good private information at the time of announcements by investigating the relation between post-earningsannouncement returns and PQS. If managers inform market participants of their private information at announcement dates, then PQS should not be associated with post-announcement returns.

Table 6 reports the regression results of the post-earnings-announcement returns on PQS, WQS, and other control variables. Specifically, we run the following regression model.

$$
\operatorname{PAR}_{i, t}=\alpha+\beta_{1} \mathrm{PQS}_{i, \mathrm{t}}+\beta_{2} \mathrm{WQS}_{\mathrm{i}, \mathrm{t}}+\gamma^{\prime} \mathbf{X}_{\mathrm{i}, \mathrm{t}}+\varepsilon_{\mathrm{i}, \mathrm{t}}
$$

where $\mathrm{PAR}_{\mathrm{i}, \mathrm{t}}$ is the post-earnings-announcement return for firm $i$ and quarter $t$, and is calculated as the return in excess over the market for the period beginning on the fourth day and ending on $60^{\text {th }}$ day past the announcement date of fiscal quarter-t earnings. $\mathbf{X}_{\mathrm{i}, \mathrm{t}}$ is the control variables, including SUE, SUR, Size, BE/ME, and PastReturn; Size is the natural logarithm of the market capitalization as of fiscal quarter-tend; $\mathrm{BE} / \mathrm{ME}$ is the natural logarithm of the book-to-market ratio as of the most recent fiscal year ending at least three month prior to fiscal quarter- $t$ end; and PastReturn is the cumulative return in excess over the market from thirty to three days prior to the earnings announcement.

Model (1) shows that the regression of PAR on PQS yields a significant and positive coefficient. Model (2) shows that WQS is positive and significant at 10\% level. However, Model (3) shows that WQS is subsumed by PQS, while the latter remains statistically significant at $10 \%$ level. 
Thus, managers' private information on quarter $t+1$ is not immediately observed by investors at earnings announcement dates, but is gradually disseminated and reflected in stock prices with a delay.

We control SUE and SUR, as well as lags of SUE and SUR, since various studies show that lags of SUE and SUR have predictive power for post-earnings-announcement returns (Bernard and Thomas (1990), Jagadeesh and Livnat (2006)). As expected, both SUE and SUR have positive coefficients although they are not significant for some specifications. Interestingly, Lagged SUE and SUR have negative coefficients. However, the significance is not robust to fixed effects, or FamaMacBeth method. Model (6) includes all the control variables. The result shows that PQS remains significantly positive. Also, Models (7) to (9) show that the predictability of PQS for the post-earningsannouncement returns is robust to fixed effects or Fama-MacBeth procedure.

Overall, Table 6 shows that across various specifications, PQS is the most consistent variable in predicting the post-earnings-announcement returns. The positive coefficient on PQS indicates a delayed response of stock prices to the information in PQS, suggesting that the information in PQS is not revealed completely at earnings announcement dates. These results provide an interesting perspective relative to previous studies which discuss about asymmetric incentives of managers to disclose good news versus bad news. Some studies show managers withhold bad news while releasing good news quickly (e.g., Kothari, Shu, and Wysocki (2008), Roychowdhury and Sletten (2012)). Others examine managerial incentives to delay good news for personal benefits, such as stock option awards (e.g., Yermack (1997), Aboody and Kasznik (2000)). Our results regarding the post-announcement returns are consistent with delaying good news. To further investigate managerial incentives behind delaying good news, we examine the relation between announcement returns and PQS. 


\subsection{Announcement Returns and Private Information}

The relation between PQS and the post-announcement returns implies that managers do not reveal private information at the time earnings announcements, upon seeing a strong post-quarter performance. Then, do managers actively maneuver the market's expectation at announcements? We try to answer this question by examining the relation between the announcement returns and PQS. Specifically, we regress announcement returns on PQS, WQS, and control variables. Table 7 provides our results.

First, we comment on control variables. Consistent with the literature, Size tends to have significant and negative coefficients and the relation is robust to the most specifications. $\mathrm{BE} / \mathrm{ME}$ has positive coefficients, but they are insignificant once SUE is controlled. PastReturn is negatively related with announcement return, albeit often insignificant, implying that there is return reversal after announcements. This is consistent with the notion that market makers demand higher expected returns (thus, higher return reversal) around earnings announcements (So and Wang, 2014). Overall, examining control variables suggests that our sample shares the common characteristics of asset pricing relations with bigger samples of other financial studies.

We also include contemporaneous SUE and SUR as well as lagged SUE and SUR. As expected, SUE and SUR both are significantly related with announcement returns. Both lagged SUE and lagged SUR tend to have negative coefficients, albeit insignificant for many specifications, implying our sample does not display the persistence of earnings surprises and revenue surprises.

Now, we turn our attention to the main explanatory variables. Consistent with Table 5, WQS has a positive and significant relation with announcement returns even after various firm characteristics, SUE, and SUR are controlled for. Interestingly, PQS enters the regression models with a significantly negative coefficient for the most specifications. This implies that PQS affects the tone 
of disclosures at the time of announcements. In fact, our results suggest that managers may issue negative soft "guidance" with respect to the future when post-quarter-end sales information is positive. In the next section, we provide evidence that when PQS is high, managers indeed issue pessimistic forecasts and use negative tone in conference calls.

The negative relation between PQS and announcement return can have several interpretation. One would be the litigation risk. Extant studies suggest that litigation risks discourage managers to make optimistic projections (Skinner, 1994, 1997). Therefore, when their expectation for the next quarter is high, managers may lower investors' expectation to avoid potential lawsuits. Another possible interpretation is that managers, upon seeing strong post-quarter-end results, may not simply defer that good news, but actually use a negative tone to increase the predictable portion of their company's stock price. This would be to their private advantage if they could use the open window following announcements to trade their company's stock. We examine this explanation further in the next section by investigating the stock price movement and insider trades after announcement dates.

In sum, Table 7 documents the negative relation between PQS and announcement returns. This result, together with the predictability of PQS for the post-announcement returns, suggests that managers may intentionally understate their expectation for the next quarter at the time of earnings announcements. Thus, the predictability of stock prices increases as managers' private information is gradually diffused and reflected in stock prices. This opens up opportunities for managers to take advantage for their personal gain.

\section{Accruals, Bundled Forecasts, Managerial Tones, and Insider Trading}

The documented patterns in returns around announcement dates and PQS suggest corporate insiders maneuver the market's expectation during earnings announcements. In this section, we formally test 
whether managers indeed try to influence market's expectation given strong post-quarter performance. There are various available channels managers may make use of to manipulate the expectation. For example, managers can affect the market by directly altering earnings through discretionary accruals. Or they can use softer channels such as management forecasts or nuanced tone in conference calls. We also examine how managers' private information, measured using PQS, affects managers' incentives for personal trading.

\subsection{Discretionary Accruals}

A few papers suggest managers use discretionary accruals to communicate their private information, showing discretionary accruals are positively associated with future profitability or dividend changes (e.g., Demski (1998), Subramanyam (1996), Louis and Robinson (2005)). Therefore, we study whether managers send a signal using discretionary accruals to lower the market's expectation of future earnings.

Each quarter, discretionary accruals (DA) are estimated using an extended Jones (1991) model from a cross-section regression as follow (Larcker and Richardson, 2004). ${ }^{4}$

$$
\mathrm{TA}=\alpha_{0}+\alpha_{1}(1 / \mathrm{A})+\alpha_{2}(\Delta \mathrm{REV}-\Delta \mathrm{REC})+\alpha_{3} \mathrm{PPE}+\mathrm{BE} / \mathrm{ME}+\mathrm{CFO}+\varepsilon
$$

where TA is total accruals scaled by lagged total assets; A is total assets; PPE is gross property plant and equipment in quarter $t$ scaled by total assets at $t-1 ; \Delta \mathrm{REV}$ is the change in revenue from quarter $t-1$ to $t$ scaled by total asset at $t-1$; and $\triangle \mathrm{REC}$ is net receivables in quarter $t$ less net receivables in $t-1$

\footnotetext{
${ }^{4}$ We follow Larcker and Richardson (2004) who extend the modified Jones model by adding book-to-market ratio and cash flow from operation. Dechow, Sloan, and Sweeney (1995) show that the modified Jones model exhibits the most power in detecting earnings management. However, McNichols (2002) highlights the importance of operating cash flows in accrual estimation. We also measure accruals from the statement of cash flows instead of balance sheet, following Hribar and Collins (2001).
} 
scaled by total assets at $t-1 ; \mathrm{BE} / \mathrm{ME}$ is the book-to-market ratio; $\mathrm{CFO}$ is the operating cash flow scaled by lagged total asset. Fiscal quarter dummies are also included in the regression. And, the discretionary accruals $(\mathrm{DA})$ is obtained from the residuals of the regression, $\varepsilon$.

If managers indeed lower the expectation through discretionary accruals, we expect to observe a negative relation between discretionary accruals and PQS. We run the following regression to test this prediction.

$$
\mathrm{DA}=\alpha+\beta_{1} \mathrm{WQS}+\beta_{2} \mathrm{PQS}+\beta_{3} \mathrm{SUE}+\beta_{4} \mathrm{SUR}+\varepsilon
$$

Panel A of Table 8 reports the results of above regression model. Model (1) shows the result of a simple regression of DA on WQS. The regression suggests that within-quarter sales measure for quarter $t$ is not significantly related with the level of discretionary accruals. The insignificance of WQS is sensible, because WQS is strongly correlated with the revenue growth and earnings growth which are already accounted for when discretionary accruals are estimated. Model (2) regresses DA on PQS, which enters the model with an insignificant coefficient. Insignificance of PQS are observed throughout different specifications, implying that the negative relation between announcement returns and PQS is not due to earnings management through discretionary accruals.

The only variable that enters regression models with a significant coefficient is SUE. The positive coefficient on SUE implies that there is a high correlation between the level of discretionary accruals and earnings surprises. However, a caution should be made not to interpret this result such that a higher SUE is due to earnings management. It may be the case that firms with high SUE tend to have high growth expectation, thus need additional working capital which is captured as discretionary accruals. 
Studies on earnings management have shown that firms have strong incentives to manage earnings to meet and beat a benchmark, such as analysts' earnings forecasts or previous year's reported earnings (Burgstahler and Dichev (1997), Bartov, Givoly, and Hayn (2002), Bhojraj, Hribar, Picconi, McInnis (2009), Roychowdhury (2006)). Therefore, in Panel B, we introduce dummy variables that indicate whether firms are on the verge of beating or missing analysts' forecasts, and examine whether managers' incentives for earnings management through discretionary accruals are affected by the likelihood of beating or missing analysts' forecasts.

We follow Bhojraj, Hribar, Picconi, McInnis (2009) to define three dummy variables - Meet, Beat, and Miss; Meet is a dummy variable that takes one if a firm has earnings that were within plus or minus half-a-cent of the consensus forecast, and zero otherwise; Beat is a dummy variable that takes one if a firm has reported earnings between half-a-cent and one-and-a-half cents above the consensus forecast, and zero otherwise; Miss is a dummy variable that takes one if a firm has reported earnings between half-a-cent and one-and-a-half cents below the consensus forecast, and zero otherwise. We also include interaction terms of these dummy variables with PQS to the regression model in Equation (3).

Panel B shows that Beat has a significant and positive coefficient, suggesting that firms tend to use discretionary accruals more aggressively when they are on the verge of beating the benchmark. The coefficients on Miss are negative and significant for many specifications. This result suggest that firms that are unable to beat the benchmark actually tend to increase earnings quality (i.e., decrease discretionary accruals) for future fiscal quarters.

The more interesting variables are the interaction terms of the dummies with PQS. If managers use discretionary accruals to manage down the market's expectation, we would observe negative coefficients on the interaction terms. We find some evidence, albeit weak, that for firms that marginally 
miss analyst consensus, the PQS is negatively related to discretionary accruals. This suggests that managers of firms that marginally miss analysts' forecasts may use discretionary accruals to lower the market's expectation, upon facing positive post-quarter sales performance. However, PQS is not strongly related to discretionary accruals for other types of firms, indicating that the discretionary accruals are not the main source of the negative relation between PQS and announcement returns.

\subsection{Bundled forecasts}

Can the negative relation between PQS and announcement returns be attributed to the pessimistic forecasts provided by managements at the time of announcements? To answer this, we create a sample of managements' forecasts issued concurrently with earnings announcements ("bundled" forecasts) and investigate the relation between the bundled forecasts and PQS. ${ }^{5}$ If managers issue pessimistically biased forecasts of next quarter earnings (or revenue) amid high prospects, the likelihood of ex-post realized earnings being higher than managements' forecasts would be positively related to PQS. We test this prediction using a Probit model.

The dependent variable of our model is a dummy variable equal to one if the management forecast is pessimistic compared to realized earnings (or revenue) and zero otherwise. We assume the management forecast to be pessimistic if the related management forecast error is less than a cutoff value. The management forecasting error for EPS is defined as $\left(\mathrm{MF}_{\mathrm{i}, t+1}-\mathrm{A}_{\mathrm{i}, \mathrm{t}+1}\right)$ scaled by $\mathrm{P}_{\mathrm{i}, \mathrm{t}+1}$, where $\mathrm{MF}_{\mathrm{i}, \mathrm{t}+1}$ is the management forecast for quarter $t+1$, and $\mathrm{A}_{\mathrm{i}, \mathrm{t}+1}$ is realized quarterly EPS amount. The

\footnotetext{
${ }^{5}$ Approximately, $32 \%$ of earnings announcements in our sample are bundled with managements' forecast of the next quarter. This ratio is consistent with Rogers and Van Buskirk (2013) who document that about 29\% of announcements are bundled for the post-Reg FD period.
} 
forecasting error for revenue is defined as $\left(\mathrm{MF}_{\mathrm{i}, t+1}-\mathrm{A}_{\mathrm{i}, \mathrm{t}+1}\right)$ scaled by $\mathrm{MF}_{\mathrm{i}, \mathrm{t}+1}$. We use the cutoff value of -0.002 for earnings (10 cents for a stock of \$50) and -0.001 for revenue. ${ }^{6}$

Table 9 reports the results of the Probit regressions. Panel A uses management forecasts of EPS to calculate the dependent variable, while Panel B makes use of revenue forecasts of managements. We report the average marginal probability change for a one-standard deviation change in the values of the covariates.

The results shows that the likelihood of ex-post earnings or revenue being higher than management forecasts is positively and significantly related to PQS. A one standard deviation increase in PQS is associated about 5\% to 7\% (6\% to 8\%) increase in the probability of management forecasts at the time of announcements being ex-post pessimistic relative to realized earnings (revenue). Thus, Table 9 provides evidence consistent with our conjecture that managers actively attempt to depress stock prices through guidance upon seeing high level of PQS.

\subsection{Managerial Tone of Conference Calls}

We also examine whether managers make use of a negative tone in communicating with market participants to manage down their expectation. We investigates the relation between the managerial tone in conference call transcripts and their private information, proxied by PQS. The dependent variable is TONE, defined as $\log (1+$ number of positive words $)$ minus $\log (1+$ number of positive words + number of negative words). We follow Loughran and McDonald (2011) for the classification of positive and negative words.

Table 10 reports the results of regression of TONE on PQS and control variables. The results show that TONE is positively related to WQS, while it has a negative relation with PQS. However,

\footnotetext{
${ }^{6}$ Both of the threshold values are at approximately 40 percentile of the distributions. This number is roughly consistent with Rogers and Van Buskirk (2013) who classify about 35\% of announcements as negative surprises. Using different threshold values does not change the inference.
} 
WQS is subsumed once SUE and SUR are controlled for, while PQS remains significant. The significant and negative relation of PQS with TONE implies that when managers have positive private information, they use more negative tone in communicating with the market.

Overall, the analyses in Table 9 and 10 provide evidence that managers intentionally maneuver stock prices when they have good information with respect to following quarter. Consequently, announcement returns are negatively related with PQS, while the post-announcement returns are positively related with PQS. In sum, evidence from bundled forecasts and managerial tone in conference calls suggest that managers use various "soft" sources of communication to intentionally manage down stock prices.

\subsection{Insider Trading}

We show a negative relation of PQS with announcement returns and a positive relation with postannouncement returns. PQS is also related to more pessimistic guidance or less positive managerial tone of conference calls. These results suggest that managers may intentionally understate their expectation to create an opportunity for insider trading. Thus, we conjecture that the negative relation between PQS and announcement returns is stronger when insiders buy their firms' shares subsequently. We also conjecture that the positive predictability of PQS for the post-earningsannouncement returns is stronger when insiders' purchase takes place. Table 11 examines insiders' trades around earnings announcements. Specifically, we run the following regression;

$$
\mathrm{R}(\mathrm{t}, \mathrm{T})=\alpha+\beta_{1} \mathrm{PQS}+\beta_{2} \text { Buy }+\beta_{3} \text { Sell }+\beta_{4} \text { Buy } \times \mathrm{PQS}+\beta_{5} \text { Sell } \times \mathrm{PQS}+\gamma^{\prime} \mathbf{X}+\varepsilon,
$$

where $R(t, T)$ is excess return over the market around announcement dates; Buy is an indicator variable that equals one if management team is a net buyer during the 20 trading day period following earnings announcement, and zero otherwise; Sell is an indicator variable that equals one if management team 
is a net seller, and zero otherwise; $\mathbf{X}$ is a set of control variables. Firm and time subscripts are suppressed. In estimating Equation (4), we do not use firm fixed effects or Fama-MacBeth regressions, because there is no observed insider trade for a few firms and quarters. Instead, we report the $t$ statistics based standard errors clustered at firm level.

Panel A summarizes the frequencies of insider purchases and sales based on quartiles of PQS and signs of announcement returns. The panel shows that there are significantly more insider sales than purchases. Only $2 \%$ of announcements are followed by insider purchases, while approximately $31 \%$ of announcements are followed by insider sales. This suggests that insiders typically obtain stocks through stock options and sell those vested stocks due to reasons such as diversification or liquidity.

Panel B uses announcement returns, R(-1,3), as a dependent variable. Negative coefficients on Buy and positive coefficients on Sell indicate that insiders tend to purchase following a negative announcement and sell subsequently after a positive announcement. These results are consistent with the literature that shows insiders are contrarian (Piotroski and Roulstone (2005), and Jenter (2005)).

More interestingly, we find negative coefficients on the interaction between Buy and PQS throughout different specifications. Consistent with our conjecture, the negative relation between post-quarter RTCS and announcement returns is stronger when insiders purchase their firms' shares subsequently. This implies that insiders understate their private information to purchase undervalued stocks prior to the price increase.

The interaction between Sell and PQS is not significant, appearing to be inconsistent with our conjecture. However, the literature shows that managers provide higher quality disclosures before selling shares due to litigation cost, while they provide lower quality disclosure prior to purchasing for personal advantage (Rogers, 2008). Thus, the negative coefficients on the interaction term of PQS 
with Buy and the insignificant coefficients on its interaction with Sell is consistent with the extant literature.

Panel C reports the regression results of post-earnings announcement returns over various holding periods. The first two columns of the panel use $\mathrm{R}(4,60)$ as the dependent variable. Neither of Buy and Sell is strongly related with the post-announcement returns. However, consistent with our conjecture, the positive predictability of PQS for the post-earnings-announcement returns is particularly strong when insiders' purchases take place.

The post-announcement price increases may indicate price pressure due to insider purchases, rather than insiders' superior information with respect to PQS. Therefore, we divide postannouncement returns into two holding periods; $\mathrm{R}(4,20)$ and $\mathrm{R}(21,60)$. $\mathrm{R}(4,20)$ is contemporaneous return with insider trades, since Buy and Sell are defined from insider trades during the 20 trading day period following earnings announcement.

The results show that the positive relation between insider purchases with post-announcement returns is not due to price pressure, reinforcing our conjecture that insiders intentionally understate their expectation at the announcements upon seeing strong post-quarter-end results. The coefficient on the interaction between PQS and Buy is not significant for the contemporaneous return, $\mathrm{R}(4,20)$, while it is significantly positive for $\mathrm{R}(21,60)$, indicating that the price movement is due to information diffusion rather than price pressure.

Overall, the results in Table 11 are consistent with our conjecture, suggesting that corporate insiders attenuate guidance information during announcements to purchase undervalued stocks prior to the price increase. 


\section{Conclusion}

In this paper, we study the relation between managers' private information and its effects on corporate disclosures and insider trading, utilizing multiple proprietary big data sources. First, we develop a firmlevel real-time corporate sales index for US retail stores and demonstrate the usefulness of the index in predicting firms' fundamentals and future returns. We show that the within-quarter RTCS has strong predictive power for revenue surprises, earnings surprises, and excess returns around quarterly earnings announcements. The return differential between high and low RTCS firms around earnings announcement dates is $3.40 \%$.

Second, we use post-quarter RTCS as proxy for managers' private information and study how their decision for disclosure timing and contents are affected by their private information. We provide evidence against the Timely Disclosure Hypothesis - managers not only withhold, but attenuate or reverse, good post-quarter private information. Our post-quarter RTCS is negatively related to announcement returns, but positively to post-announcement returns. This pattern in returns is more pronounced in the presence of post-announcement insider purchases. Our central interpretation is that managers intentionally understate their expectations about the next quarter to increase the predictability of stock prices post announcement for their personal advantage.

Finally, our analyses show that managers' forecasts and tones in conference calls are, according to objective measures, more pessimistic when managers have positive post-quarter information, suggesting that at announcement they actively manage down investor expectations and stock price. This last fact - that objective measures of guidance and tone are negatively correlated with postquarter private information - is important. One could otherwise argue that managers cannot control how investors and analysts hear their announcement guidance and voluntary disclosures. If there is noise in the process (and there undoubtedly is) and, say, investors hear something more negative than 
managers intend, then it wouldn't be surprising to see our observed post-announcement return reversals and greater insider purchases. However, this explanation becomes badly stretched because it predicts managers at announcement offer more positive - not more negative - guidance and calltranscript sentiment.

Unfortunately, we do not see any coherent alternative hypothesis - other than managerial manipulation for personal gain - to explain our particular rejection of the Timely Disclosure Hypothesis. 


\section{References}

Abarbanell, Jeffry S. and Victor L. Bernard, 1992, Tests of Analysts' Overreaction/Underreaction to Earnings Information as an Explanation for Anomalous Stock Price Behavior, Journal of Finance 47, 1181-1207.

Aboody, David and Ron Kasznik, 2000, CEO stock option awards and the timing of corporate voluntary disclosures, Journal of Accounting and Economics 29, 73-100.

Baginski, Stephen P., John M. Hassell, and Michael D. Kimbrough, 2002, The Effect of Legal Environment on Voluntary Disclosure: Evidence from Management Earnings Forecasts Issued in U.S. and Canadian Markets, The Accounting Review 77, 25-50.

Bartov, Eli, Lucile Faurel, and Partha Mohanram, 2015, Can Twitter Help Predict Firm-Level Earnings and Stock Returns?, Working paper.

Bartov, Eli, Dan Givoly, and Carla Hayn, 2002, The rewards to meeting or beating earnings expectations, Journal of Accounting and Economics 33, 173-204.

Berkman, Henk and Cameron Troung, 2009, Event Day 0? After-Hours Earnings Announcements, Journal of Accounting Research 47, 71-103

Bernard, Victor L., and Douglas J. Skinner, 1996, What motivates managers' choice of discretionary accruals?, Journal of Accounting and Economics 22, 313-325.

Bernard, Victor L., and Jacob K. Thomas, 1989, Post-Earnings-Announcement Drift: Delayed Price Response or Risk Premium?, Journal of Accounting Research 27, 1-36.

Bernard, Victor L., and Jacob K. Thomas, 1990, Evidence That Stock Prices Do Not Fully Reflect The Implications of Current Earnings For Future Earnings, Journal of Accounting and Economics 13, 305304.

Bhojraj, Sanjeev, Paul Hribar, Marc Picconi, and John McInnis, 2009, Making Sense of Cents: An Examination of Firms That Marginally Miss or Beat Analyst Forecasts, Journal of Finance 64, 2361-2388.

Burgstahler, David and Ilia Dichev, 1997, Earnings management to avoid earnings decreases and losses, Journal of Accounting and Economics 24, 99-126.

Chen, Hailiang, Prabuddha De, Yu Hu, and Byoung-Hyoun Hwang, 2015, Wisdom of Crowds: The Value of Stock Opinions Transmitted Through Social Media, Review of Financial Studies, forthcoming.

Dechow, Patricia M., Richard G. Sloan, and Amy P. Sweeney, 1995, Detecting Earnings Management, The Accounting Review 70, 193-225.

DeFond Mark L. and Chul W. Park, 2001, The Reversal of Abnormal Accruals and the Market Valuation of Earnings Surprises, The Accounting Review 76, 375-404. 
Demski, Joel S., 1998, Performance measure manipulation, Contemporary Accounting Research 15, 261 285.

Druz, Marina, Ivan Petzev, Alexander F. Wagner, and Richard J. Zeckhauser, 2016, Reading Managerial Tone: How Analysts and the Market Respond to Conference Calls, Working paper

Ertimur Yonca, Joshua Livnat, and Minna Martikainen, 2003, Differential Market Reactions to Revenue and Expense Surprises, Review of Accounting Studies 8, 185-211

Graham, John R., Campbell R. Harvey, and Shiva Rajgopal, 2005, The economic implications of corporate financial reporting, Journal of Accounting and Economics 40, 3-73.

Hribar, Paul and Daniel W. Collins, 2001, Errors in Estimating Accruals: Implications for Empirical Research, Journal of Accounting Research 40, 105-134.

Jagadeesh, Narasimhan and Joshua Livnat, 2006, Revenue Surprises and Stock Returns, Journal of Accounting and Economics 41, 147-171.

Jagadeesh, Narasimhan and Joshua Livnat, 2006, Post-Earnings-Announcement Drift: The Role of Revenue Surprises, Financial Analysts Journal 62, 22-34.

Jenter, Dirk, 2005, Market Timing and Managerial Portfolio Decisions, Journal of Finance 60, 19031949.

Jones, Jennifer J., 1991, Earnings Management During Import Relief Investigations, Journal of Accounting Research 29, 193-228.

Kasanen, Eero, Juha Kinnunen, and Jyrki Niskanen, 1996, Dividend-based earnings management: Empirical evidence from Finland, Journal of Accounting and Economics 22, 283-312.

Kothari, S. P., Susan Shu, and Peter D. Wysocki, 2008, Do Managers Withhold Bad News? Journal of Accounting Research 47, 241-276.

Larcker, David F. and Scott T. Richardson, 2004, Fees Paid to Audit Firms, Accrual Choices, and Corporate Governance, Journal of Accounting Research 42, 625-658.

Loughran, Tim and Bill McDonald, 2011, When is a liability not a liability? Textual analysis, dictionaries, and 10-ks, Journal of Finance 66, 35-65.

Louis, Henock and Dahlia Robinson, 2005, Do managers credibly use accruals to signal private information? Evidence from the pricing of discretionary accruals around stock splits, Journal of Accounting and Economics 39, 361-380.

Mayew, William J. and Mohan Venkatachalam, 2012, The Power of Voice: Managerial Affective States and Future Firm Performance, Journal of Finance 67, 1-43.

McNichols, Maureen F., 2002, The Quality of Accruals and Earnings: The Role of Accrual Estimation Errors: Discussion, The Accounting Review 77, 61-69. 
Ozik, Gideon and Ronnie Sadka, 2013, Big data and information edge, Hedge Funds Review December 2013/January 2014, 32-34.

Piotroski, Joseph D. and Darren T. Roulstone, 2005, Do insider trades reflect both contrarian beliefs and superior knowledge about future cash flow realizations? Journal of Accounting and Economics 39, 55 81.

Rogers, Jonathan L., 2008, Disclosure Quality and Management Trading Incentives, Journal of Accounting Research 46, 1265-1296.

Rogers, Jonathan L. and Andrew Van Buskirk, 2013, Bundled forecasts in empirical accounting research, Journal of Accounting and Economics 55, 43-65.

Roychowdhury, Sugata, 2006, Earnings management through real activities manipulation, Journal of Accounting and Economics 42, 335-370.

Roychowdhury, Sugata and Ewa Sletten, 2012, Voluntary Disclosure Incentives and Earnings Informativeness, The Accounting Review 87, 1679-1708.

Sankar, Mandira Roy and K. R. Subramanyam, 2001, Reporting Discretion and Private Information Communication through Earnings, Journal of Accounting Research 39, 365-386.

Skinner, Douglas J., 1994, Why firms voluntarily disclose bad news, Journal of Accounting Research 32, 38-60.

Skinner, Douglas J., 1997, Earnings disclosures and stockholder lawsuits, Journal of Accounting and Economics 23, 249-282.

So Eric C., and Sean Wang, 2014, News-driven Return Reversals: Liquidity Provision Ahead of Earnings Announcements, Journal of Financial Economics 114, 20-35

Subramanyam K.R., 1996, The pricing of discretionary accruals, Journal of Accounting and Economics 22, 249-281.

Tetlock, Paul C., 2007, Giving content to investor sentiment: The role of media in the stock market, Journal of Finance 62, 1139-1168.

Tetlock, Paul C., Maytal Saar-Tsechansky, and Sofus Macskassy, 2008, More Than Words: Quantifying Language to Measure Firms’ Fundamentals, Journal of Finance 63, 1437-1467

Tucker, Jennifer W., and Paul A. Zarowin, 2006, Does Income Smoothing Improve Earnings Informativeness?, The Accounting Review 81, 251-270

Yermack, David, 1997, Good Timing: CEO Stock Option Awards and Company News Announcements, Journal of Finance 52, 449-476. 


\section{Table 1: Sample Firms}

This table provides the list of firms in the sample, their tickers, headquarter locations, and US sales amounts as of 2014 . US sales amounts are obtained from National Retail Federations and Yahoo! Finance.

\begin{tabular}{|c|c|c|c|c|}
\hline No & Ticker & Name & $\mathrm{HQ}$ & US Retail Sales (Million USD) \\
\hline 1 & AEO & American Eagle Outfitters, Inc. & Pittsburgh, PA & 3,283 \\
\hline 2 & ANF & Abercrombie \& Fitch Co. & New Albany, OH & 3,744 \\
\hline 3 & ANN & Ann Inc. & New York, NY & 2,533 \\
\hline 4 & ASNA & Ascena Retail Group Inc. & Suffern, NY & 4,713 \\
\hline 5 & BBBY & Bed Bath \& Beyond Inc. & Union, NJ & 11,708 \\
\hline 6 & BBY & Best Buy Co., Inc. & Richfield, MN & 35,957 \\
\hline 7 & BIG & Big Lots Inc. & Columbus, $\mathrm{OH}$ & 5,177 \\
\hline 8 & CASY & Casey's General Stores, Inc. & Ankeny, IA & 7,767 \\
\hline 9 & $\mathrm{CHS}$ & Chico's FAS Inc. & Fort Myers, FL & 2,675 \\
\hline 10 & COST & Costco Wholesale Corporation & Issaquah, WA & 79,694 \\
\hline 11 & CVS & CVS Health Corporation & Woonsocket, RI & 67,974 \\
\hline 12 & DDS & Dillard's Inc. & Little Rock, AR & 6,490 \\
\hline 13 & DKS & Dick's Sporting Goods Inc. & Coraopolis, PA & 6,811 \\
\hline 14 & DLTR & Dollar Tree, Inc. & Chesapeake, VA & 8,390 \\
\hline 15 & DSW & DSW Inc. & Columbus, $\mathrm{OH}$ & 2,496 \\
\hline 16 & EXPR & Express Inc. & Columbus, $\mathrm{OH}$ & 2,165 \\
\hline 17 & FDO & Family Dollar Stores Inc. & Matthews, NC & 10,489 \\
\hline 18 & GES & Guess' Inc. & Los Angeles, CA & 2,418 \\
\hline 19 & GNC & GNC Holdings Inc. & Pittsburgh, PA & 2,613 \\
\hline 20 & GPS & The Gap, Inc. & San Francisco, CA & 13,071 \\
\hline 21 & HD & The Home Depot, Inc. & Atlanta, GA & 74,203 \\
\hline 22 & HTSI & Harris Teeter Supermarkets Inc. & Matthews, NC & 4,710 \\
\hline 23 & $\mathrm{JCP}$ & J. C. Penney Company, Inc. & Plano, TX & 12,184 \\
\hline 24 & JOSB & Joseph A. Bank Clothiers, Inc. & Hampstead, MD & 3,253 \\
\hline 25 & JWN & Nordstrom Inc. & Seattle, WA & 13,259 \\
\hline 26 & KORS & Michael Kors Holdings Limited & London, UK & 4,371 \\
\hline 27 & $\mathrm{KR}$ & The Kroger Co. & Cincinnati, $\mathrm{OH}$ & 103,033 \\
\hline 28 & KSS & Kohl's Corp. & Menomonee Falls, WI & 19,023 \\
\hline 29 & LL & Lumber Liquidators Holdings, Inc. & Toano, VA & 1,047 \\
\hline 30 & LB & L Brands & Columbus, $\mathrm{OH}$ & 10,303 \\
\hline 31 & M & Macy's, Inc. & Cincinnati, $\mathrm{OH}$ & 28,027 \\
\hline 32 & MW & The Men's Wearhouse, Inc. & Houston, TX & 3,253 \\
\hline 33 & PIR & Pier 1 Imports, Inc. & Fort Worth, TX & 1,866 \\
\hline 34 & RAD & Rite Aid Corporation & Camp Hill, PA & 26,528 \\
\hline 35 & $\mathrm{RH}$ & Restoration Hardware Holdings, Inc. & Corte Madera, CA & 1,867 \\
\hline 36 & ROST & Ross Stores Inc. & Pleasanton, CA & 11,032 \\
\hline 37 & SHLD & Sears Holdings Corporation & Hoffman Estates, IL & 25,763 \\
\hline 38 & SIG & Signet Jewelers Limited & Hamilton, Bermuda & 5,736 \\
\hline 39 & SKS & Saks Inc. & New York City, NY & 3,148 \\
\hline 40 & SVU & SUPERVALU Inc. & Eden Prairie, MN & 11,499 \\
\hline 41 & SWY & Safeway Inc. & Pleasanton, CA & 36,330 \\
\hline 42 & TFM & The Fresh Market, Inc. & Greensboro, NC & 1,753 \\
\hline 43 & TGT & Target Corp. & Minneapolis, MN & 72,618 \\
\hline 44 & TIF & Tiffany \& Co. & New York, NY & 4,250 \\
\hline 45 & TJX & The TJX Companies, Inc. & Framingham, MA & 22,206 \\
\hline 46 & URBN & Urban Outfitters Inc. & Philadelphia, PA & 3,323 \\
\hline 47 & WBA & Walgreens Boots Alliance, Inc. & Deerfield, IL & 72,671 \\
\hline 48 & WFM & Whole Foods Market, Inc. & Austin, TX & 13,642 \\
\hline 49 & WMT & Wal-Mart Stores Inc. & Bentonville, AR & 343,624 \\
\hline \multirow[t]{4}{*}{50} & WSM & Williams-Sonoma Inc. & San Francisco, CA & 4,591 \\
\hline & & & Total & $1,219,282$ \\
\hline & & & Average & 24,386 \\
\hline & & & Median & 7,289 \\
\hline
\end{tabular}




\section{Table 2: Summary Statistics}

Panel A shows the descriptive statistics of main variables, and Panel B reports correlations. The upper right corner of Panel B reports Pearson correlations and the lower left corner of the table provides Spearman correlations. WQS is the real-time corporate sales measured for fiscal quarter $t$. The quarterly revenue growth for firm $i$ as of fiscal quarter $t$ is calculated as $\mathrm{S}_{i, t} / \mathrm{S}_{\mathrm{i}, t-1}$ minus one, where $\mathrm{S}_{\mathrm{i}, \mathrm{t}}$ is the quarterly revenue as of fiscal quarter $t$ for firm $i$. The SUR for stock $i$ in quarter $t$ is calculated as $\left[\left(S_{i, t}-S_{i, t-4}\right)-r_{i, t}\right] / \sigma_{i, t}$ where $\sigma_{i, t}$ and $r_{i, t}$ are the standard deviation and average, respectively, of $\left(S_{i, t}-S_{i, t-4}\right)$ over the preceding eight quarters. The SUE is estimated as $\left(A E_{i, t}-F_{i, t}\right) / P_{i, t}$, where $A E_{i, t}$ is quarterly earnings per share announced for quarter $t$ of stock $i, \mathrm{FE}_{\mathrm{i}, \mathrm{t}}$ is mean analysts' forecasted EPS, and $\mathrm{P}_{\mathrm{i}, \mathrm{t}}$ is quarter-end price. The announcement return is calculated as the return in excess over the market during the period of one day before the earnings announcement date and three days after the announcement date. The post-earnings-announcement return (PAR) is the return of each firm in excess over the market for the period beginning on 4 days after the announcement dates for fiscal quarter- $t$ earnings and ending on 60 days after the announcement dates. $p$-values of correlations are reported in square brackets.

Panel A: Descriptive Statistics

\begin{tabular}{ccccccc}
\hline Variable & WQS & Rev. Growth & SUR & SUE & Ann. Return & PAR \\
\hline $\mathrm{N}$ & 918 & 894 & 890 & 869 & 918 & 914 \\
Mean & 0.0336 & 0.0271 & 0.0194 & 0.0011 & 0.0066 & 0.0018 \\
Std Dev & 0.3164 & 0.2091 & 1.6619 & 0.0073 & 0.0887 & 0.1290 \\
$25^{\text {th }}$ Pctl & -0.0960 & -0.0723 & -0.8717 & 0.0000 & -0.0409 & -0.0762 \\
Median & 0.0237 & 0.0148 & 0.0950 & 0.0005 & 0.0028 & -0.0017 \\
$75^{\text {th }}$ Pctl & 0.1675 & 0.1174 & 0.9837 & 0.0016 & 0.0519 & 0.0678 \\
\hline
\end{tabular}

Panel B: Correlations

\begin{tabular}{ccccccc}
\hline & WQS & Rev. Growth & SUR & SUE & Ann. Return & PAR \\
\hline WQS & & 0.628 & 0.140 & 0.082 & 0.127 & 0.064 \\
& & {$[0.000]$} & {$[0.000]$} & {$[0.013]$} & {$[0.000]$} & {$[0.054]$} \\
Rev. Growth & 0.627 & & 0.232 & 0.086 & 0.164 & 0.051 \\
& {$[0.000]$} & & {$[0.000]$} & {$[0.010]$} & {$[0.000]$} & {$[0.131]$} \\
SUR & 0.137 & 0.205 & & 0.069 & 0.175 & 0.067 \\
& {$[0.000]$} & {$[0.000]$} & & {$[0.039]$} & {$[0.000]$} & {$[0.046]$} \\
SUE & 0.065 & 0.099 & 0.235 & & 0.059 & 0.111 \\
& {$[0.048]$} & {$[0.003]$} & {$[0.000]$} & & {$[0.076]$} & {$[0.001]$} \\
Ann. Return & 0.154 & 0.164 & 0.126 & 0.261 & & 0.066 \\
& {$[0.000]$} & {$[0.000]$} & {$[0.000]$} & {$[0.000]$} & & {$[0.046]$} \\
PAR & 0.091 & 0.046 & 0.051 & 0.054 & 0.035 & \\
& {$[0.006]$} & {$[0.173]$} & {$[0.126]$} & {$[0.103]$} & {$[0.286]$} & \\
\hline
\end{tabular}




\section{Table 3: Revenue growth, SUR, and Real-Time Corporate Sales Index}

Panel A shows the regressions of the quarterly revenue growth on the quarterly growth of consumer activities. Panel B reports the results of regressions of the standardized unexpected revenue (SUR) on WQS. The quarterly growth of consumer activities is calculated as the log difference between aggregated consumer activities during fiscal quarter $t$ and those during fiscal quarter $t-1$. WQS is RTCS for fiscal quarter $t$. The quarterly revenue growth for firm $i$ as of fiscal quarter $t$ is calculated as $S_{i, t} / S_{i, t-1}$ minus one, where $S_{i, t}$ is the quarterly revenue as of fiscal quarter $t$ for firm $i$. The SUR for stock $i$ in quarter $t$ is calculated as $\left[\left(S_{i, t}-S_{i, t-4}\right)-r_{i, t}\right] / \sigma_{i, t}$ where $\sigma_{i, t}$ and $r_{i, t}$ are the standard deviation and average, respectively, of $\left(\mathrm{S}_{\mathrm{i}, \mathrm{t}}-\mathrm{S}_{\mathrm{i}, \mathrm{t}-\mathrm{L}}\right)$ over the preceding eight quarters. Models (1) to (4) show the results of pooled regressions, while Model (5) shows the result of Fama-MacBeth regressions. Adjusted $\mathrm{R}^{2}$ (for pooled regressions) and the average $\mathrm{R}^{2}$ (for Fama-MacBeth regressions) are reported. The sample includes firm-quarters of US retailers with fiscal quarter ending between March 2009 and July 2014.

\section{Panel A: Revenue Growth on the Growth of Consumer Activities}

\begin{tabular}{cccccc}
\hline Model & $(1)$ & $(2)$ & $(3)$ & $(4)$ & $(5)$ \\
Coefficient & 0.414 & 0.307 & 0.417 & 0.310 & 0.290 \\
t value & {$[24.11]$} & {$[15.12]$} & {$[23.67]$} & {$[14.74]$} & {$[8.62]$} \\
Adj (Average) $\mathrm{R}^{2}$ & $39.38 \%$ & $47.03 \%$ & $37.07 \%$ & $44.98 \%$ & $23.33 \%$ \\
Fixed Effect & $\mathrm{N}$ & Time & Firm & Firm+Time & Fama-MacBeth \\
\hline Panel B: Regressions of SUR on WQS & & & & \\
\hline Model & $(1)$ & $(2)$ & $(3)$ & $(4)$ & $(5)$ \\
Coefficient & 1.155 & 0.800 & 1.128 & 0.706 & 0.795 \\
t value & {$[5.33]$} & {$[3.43]$} & {$[5.06]$} & {$[2.92]$} & {$[2.24]$} \\
Adj (Average) $\mathrm{R}^{2}$ & $2.98 \%$ & $18.93 \%$ & $4.11 \%$ & $21.07 \%$ & $3.78 \%$ \\
Fixed Effect & $\mathrm{N}$ & Time & Firm & Firm+Time & Fama-MacBeth \\
\hline
\end{tabular}




\section{Table 4: Regression of SUE on WQS}

This table reports the regression results of standardized unexpected earnings (SUE) on the within-quarter real-time corporate sales index (WQS). The SUE is estimated as $\left(A E_{i, t}-F E_{i, t}\right) / P_{i, t}$, where $A E_{i, t}$ is quarterly earnings per share announced for quarter $t$ of stock $i$, FE $E_{i, t}$ is mean analysts' forecasted $E P S$, and $P_{i, t}$ is quarter-end price. Firm quarters with stock prices below $\$ 5$ are excluded. The SUR for stock $i$ in quarter $t$ is calculated as $\left[\left(S_{i, t}-S_{i, t-4}\right)-r_{i, t}\right] / \sigma_{i, t}$ where $\sigma_{i, t}$ and $r_{i, t}$ are the standard deviation and average, respectively, of $\left(S_{i, t}-S_{i, t-4}\right)$ over the preceding eight quarters. Adjusted $R^{2}$ (for pooled regressions) and the average $\mathrm{R}^{2}$ (for Fama-MacBeth regressions) are reported. The sample includes firm-quarters of US retailers with fiscal quarter ending between March 2009 and July 2014

\begin{tabular}{|c|c|c|c|c|c|c|c|c|}
\hline Variables\Models & (1) & $(2)$ & (3) & (4) & (5) & (6) & (7) & (8) \\
\hline \multirow[t]{2}{*}{ WQS × 100} & 0.167 & & 0.148 & 0.158 & 0.201 & 0.180 & 0.172 & 0.070 \\
\hline & [2.37] & & {$[2.08]$} & [2.14] & {$[2.42]$} & [2.18] & {$[2.00]$} & {$[1.12]$} \\
\hline \multirow[t]{2}{*}{ SUR $\times 100$} & & 0.026 & 0.021 & 0.021 & & 0.037 & 0.043 & 0.031 \\
\hline & & [2.32] & [1.80] & {$[1.74]$} & & [2.91] & {$[3.18]$} & [3.15] \\
\hline \multirow[t]{2}{*}{ Lagged SUE } & & & & -0.013 & & & -0.046 & 0.346 \\
\hline & & & & {$[-0.60]$} & & & {$[-2.13]$} & {$[2.46]$} \\
\hline Adj (Average) $\mathrm{R}^{2}$ & $0.53 \%$ & $0.49 \%$ & $0.79 \%$ & $0.75 \%$ & $11.07 \%$ & $11.90 \%$ & $12.38 \%$ & $33.72 \%$ \\
\hline Fixed Effect & $\mathrm{N}$ & $\mathrm{N}$ & $\mathrm{N}$ & $\mathrm{N}$ & Time + Firm & Time + Firm & Time + Firm & Fama-MacBeth \\
\hline
\end{tabular}




\section{Table 5: Returns Around Earnings Announcement Dates}

Panel A shows the average returns during the event window by quintiles of within-quarter real-time corporate sales index (WQS). The event window is the period between one day prior to the earnings announcement date and three days afterward. Returns are calculated in excess of the market returns of the corresponding periods. Quintiles of WQS are calculated using the following process. In month $t$, we pool firms that have fiscal quarter ending during the threemonth rolling period of $t-2$ to $t$, and rank the firms based on WQS to obtain quintile cutoff values. Then, we use the quintile cutoff values to assign quintile ranks for the firms that have fiscal quarter ending in month $t$. The last row of Panel A reports the results of the hypothesis testing for the mean difference between the highest and the lowest quintiles. Panel B reports the regressions of event returns on WQS. Models (1) to (4) show the results of pooled regressions, while Model (5) shows the results of Fama-MacBeth regressions. Adjusted $R^{2}$ (for pooled regressions) and the average $R^{2}$ (for Fama-MacBeth regressions) are reported. The sample includes firm-quarters of US retailers with fiscal quarter ending between March 2009 and July 2014.

\section{Panel A: Announcement Returns by WQS Quintile}

\begin{tabular}{cccccc}
\hline Quintile & $\mathrm{N}$ & Mean & Std Dev & Median & $\mathrm{t}$ Value \\
\hline Low (Short) & 161 & $-1.26 \%$ & $9.53 \%$ & $-1.32 \%$ & -1.68 \\
2 & 184 & $-0.04 \%$ & $8.51 \%$ & $-0.21 \%$ & -0.06 \\
3 & 188 & $0.49 \%$ & $8.51 \%$ & $0.90 \%$ & 0.80 \\
4 & 205 & $1.67 \%$ & $8.82 \%$ & $0.82 \%$ & 2.72 \\
High (Long) & 180 & $2.14 \%$ & $8.76 \%$ & $1.81 \%$ & 3.27 \\
\hline HT: High - Low & 341 & $3.40 \%$ & $9.13 \%$ & & 3.43 \\
\hline
\end{tabular}

Panel B: Regressions of Announcement Returns on WQS

\begin{tabular}{cccccc}
\hline Model & $(1)$ & $(2)$ & $(3)$ & $(4)$ & $(5)$ \\
Coefficient & 0.035 & 0.035 & 0.033 & 0.032 & 0.033 \\
t value & {$[3.86]$} & {$[3.79]$} & {$[2.85]$} & {$[2.75]$} & {$[2.35]$} \\
Adj (Average) $\mathrm{R}^{2}$ & $1.49 \%$ & $2.76 \%$ & $3.02 \%$ & $4.34 \%$ & $4.22 \%$ \\
Fixed Effect & $\mathrm{N}$ & Firm & Time & Firm+Time & Fama-MacBeth \\
\hline
\end{tabular}




\section{Table 6: Post-Earning-Announcement Returns and Real-Time Corporate Sales}

This table reports the regression results of the post-earnings-announcement returns on PQS, WQS, and other control variables. The dependent variables are the return of each firm in excess over the market for the period beginning on 4 days after the quarter- $t$ earnings announcement dates and ending on 60 days after the announcement dates. The PQS is obtained from the RTCS for the period beginning after the fiscal-quarter- $t$ end and ending prior to the announcement date for quarter- $t$ earnings, and used as a proxy for managements' private information on the fiscal quarter $t+1$. The SUE is estimated as $\left(A E_{i, t}-F_{i, t}\right) / P_{i, t}, w h e r e ~ A E_{i, t}$ is quarterly earnings per share announced for quarter $t$ of stock $i, \mathrm{FE}_{\mathrm{i}, \mathrm{t}}$ is mean analysts' forecasted EPS, and $\mathrm{P}_{\mathrm{i}, \mathrm{t}}$ is quarter-end price. The SUR for stock $i$ in quarter $t$ is calculated as $\left[\left(\mathrm{S}_{\mathrm{i}, \mathrm{t}}-\mathrm{S}_{\mathrm{i}, \mathrm{t}-\mathrm{t}}\right)-\mathrm{r}_{\mathrm{i}, \mathrm{t}}\right] / \sigma_{\mathrm{i}, \mathrm{t}}$ where $\sigma_{\mathrm{i}, \mathrm{t}}$ and $\mathrm{r}_{\mathrm{i}, \mathrm{t}}$ are the standard deviation and average, respectively, of $\left(\mathrm{S}_{\mathrm{i}, \mathrm{t}}-\mathrm{S}_{\mathrm{i}, \mathrm{t}-\mathrm{u}}\right)$ over the preceding eight quarters. Size is the natural logarithm of the market capitalization as of fiscal quarter- $t$ end. $\mathrm{BE} / \mathrm{ME}$ is the natural logarithm of the book-to-market ratio as of the most recent fiscal year ending at least three month prior to fiscal quarter- $t$ end. PastReturn is the cumulative return in excess over the market from thirty to three days prior to the earnings announcement. Adjusted $\mathrm{R}^{2}$ (for pooled regressions) and the average $\mathrm{R}^{2}$ (for Fama-MacBeth regressions) are reported. The sample includes firm-quarters of US retailers with fiscal quarter ending between March 2009 and July 2014.

\begin{tabular}{|c|c|c|c|c|c|c|c|c|c|}
\hline Variables\Models & (1) & (2) & (3) & (4) & (5) & (6) & (7) & (8) & (9) \\
\hline \multirow[t]{2}{*}{ PQS } & 0.037 & & 0.033 & & & 0.037 & 0.052 & 0.053 & 0.052 \\
\hline & {$[2.33]$} & & {$[1.77]$} & & & [1.94] & {$[2.55]$} & [2.57] & {$[2.37]$} \\
\hline \multirow[t]{2}{*}{ WQS } & & 0.030 & 0.011 & & & 0.006 & -0.034 & -0.033 & -0.035 \\
\hline & & {$[1.75]$} & {$[0.50]$} & & & {$[0.25]$} & {$[-1.34]$} & {$[-1.18]$} & {$[-1.08]$} \\
\hline \multirow[t]{2}{*}{ SUE } & & & & 1.088 & & 1.526 & & -0.042 & 1.303 \\
\hline & & & & [1.32] & & [1.73] & & {$[-0.05]$} & {$[0.54]$} \\
\hline \multirow[t]{2}{*}{ Lagged SUE } & & & & -1.152 & & -0.726 & & -0.721 & 0.853 \\
\hline & & & & {$[-2.15]$} & & {$[-1.30]$} & & {$[-1.28]$} & {$[0.31]$} \\
\hline \multirow[t]{2}{*}{ SUR } & & & & & 0.008 & 0.005 & & 0.002 & -0.005 \\
\hline & & & & & [2.64] & [1.49] & & {$[0.57]$} & {$[-0.96]$} \\
\hline \multirow[t]{2}{*}{ Lagged SUR } & & & & & {$[-0.01]$} & {$[-0.01]$} & & {$[-0.00]$} & {$[0.00]$} \\
\hline & & & & & {$[-2.32]$} & {$[-2.00]$} & & {$[-1.17]$} & {$[0.47]$} \\
\hline \multirow[t]{2}{*}{ Size } & -0.007 & -0.005 & -0.007 & -0.006 & {$[-0.01]$} & {$[-0.01]$} & -0.096 & -0.094 & 0.000 \\
\hline & {$[-1.83]$} & {$[-1.45]$} & {$[-1.83]$} & {$[-1.84]$} & {$[-2.08]$} & {$[-1.74]$} & {$[-6.29]$} & {$[-5.83]$} & {$[0.01]$} \\
\hline \multirow[t]{2}{*}{$\mathrm{BE} / \mathrm{ME}$} & 0.017 & 0.015 & 0.017 & {$[0.01]$} & 0.008 & 0.015 & 0.012 & 0.012 & 0.006 \\
\hline & [2.54] & {$[2.35]$} & {$[2.56]$} & [1.24] & [1.21] & [2.07] & [1.01] & {$[0.90]$} & {$[0.50]$} \\
\hline \multirow[t]{2}{*}{ PastReturn } & -0.025 & -0.030 & -0.027 & {$[-0.03]$} & -0.018 & -0.044 & -0.059 & -0.090 & -0.027 \\
\hline & {$[-0.50]$} & {$[-0.61]$} & {$[-0.52]$} & {$[-0.61]$} & {$[-0.37]$} & {$[-0.83]$} & {$[-1.14]$} & {$[-1.65]$} & {$[-0.40]$} \\
\hline Adj (Average) $\mathrm{R}^{2}$ & $1.75 \%$ & $0.98 \%$ & $1.66 \%$ & $0.97 \%$ & $1.28 \%$ & $2.50 \%$ & $13.83 \%$ & $13.08 \%$ & $34.75 \%$ \\
\hline Fixed Effect & $\mathrm{N}$ & $\mathrm{N}$ & $\mathrm{N}$ & $\mathrm{N}$ & $\mathrm{N}$ & $\mathrm{N}$ & Time + Firm & Time + Firm & Fama-MacBeth \\
\hline
\end{tabular}




\section{Table 7: Announcement Returns and Real-Time Corporate Sales}

This table reports the regression results of announcement returns on PQS, WQS, and other control variables. The dependent variable is the returns around announcement dates for fiscal quarter-t earnings. The announcement return is calculated as the return in excess over the market during the period of one day before the earnings announcement date and three days after the announcement date. The PQS is obtained from the RTCS for the period beginning after the fiscalquarter- $t$ end and ending prior to the announcement date for quarter- $t$ earnings, and used as a proxy for managements' private information on the fiscal quarter $t+1$. The SUE is estimated as $\left(A E_{i, t}-F_{i, t}\right) / P_{i, t}$, where $A E_{i, t}$ is quarterly earnings per share announced for quarter $t$ of stock $i, F E_{i, t}$ is mean analysts' forecasted $E P S$, and $\mathrm{P}_{\mathrm{i}, \mathrm{t}}$ is quarter-end price. The SUR for stock $i$ in quarter $t$ is calculated as $\left[\left(\mathrm{S}_{\mathrm{i}, \mathrm{t}}-\mathrm{S}_{\mathrm{i}, \mathrm{t}-\mathrm{t}}\right)-\mathrm{r}_{\mathrm{i}, \mathrm{t}}\right] / \sigma_{\mathrm{i}, \mathrm{t}}$ where $\sigma_{\mathrm{i}, \mathrm{t}}$ and $\mathrm{r}_{\mathrm{i}, \mathrm{t}}$ are the standard deviation and average, respectively, of $\left(\mathrm{S}_{\mathrm{i}, \mathrm{t}}-\mathrm{S}_{\mathrm{i}, \mathrm{t}-\mathrm{u}}\right)$ over the preceding eight quarters. Size is the natural logarithm of the market capitalization as of fiscal quarter- $t$ end. $B E / M E$ is the natural logarithm of the book-to-market ratio as of the most recent fiscal year ending at least three month prior to fiscal quarter- $t$ end. PastReturn is the cumulative return in excess over the market from thirty to three days prior to the earnings announcement. Adjusted $\mathrm{R}^{2}$ (for pooled regressions) and the average $\mathrm{R}^{2}$ (for Fama-MacBeth regressions) are reported. The sample includes firm-quarters of US retailers with fiscal quarter ending between March 2009 and July 2014.

\begin{tabular}{|c|c|c|c|c|c|c|c|c|c|}
\hline Variables \Models & $(1)$ & $(2)$ & (3) & (4) & (5) & (6) & (7) & (8) & (9) \\
\hline \multirow[t]{2}{*}{ PQS } & -0.041 & & & -0.041 & -0.041 & -0.018 & -0.021 & -0.036 & -0.019 \\
\hline & {$[-3.41]$} & & & {$[-3.35]$} & {$[-3.62]$} & {$[-1.31]$} & {$[-1.63]$} & {$[-2.15]$} & {$[-1.35]$} \\
\hline \multirow[t]{2}{*}{ WQS } & 0.073 & & & 0.078 & 0.055 & 0.069 & 0.048 & 0.082 & 0.042 \\
\hline & [5.16] & & & {$[5.23]$} & [3.96] & [3.68] & {$[2.77]$} & [3.16] & {$[1.74]$} \\
\hline \multirow[t]{2}{*}{ SUE } & & 5.769 & & & 5.494 & & 5.455 & & 9.448 \\
\hline & & [11.28] & & & [10.32] & & {$[9.24]$} & & [4.99] \\
\hline \multirow[t]{2}{*}{ Lagged SUE } & & -0.789 & & -0.612 & -0.578 & -0.448 & -0.233 & -0.562 & -4.011 \\
\hline & & {$[-2.38]$} & & {$[-1.67]$} & {$[-1.71]$} & {$[-1.18]$} & {$[-0.66]$} & {$[-0.26]$} & {$[-2.31]$} \\
\hline \multirow[t]{2}{*}{ SUR } & & & {$[0.01]$} & & {$[0.01]$} & & {$[0.01]$} & & 0.004 \\
\hline & & & {$[5.79]$} & & [3.58] & & [3.49] & & {$[0.94]$} \\
\hline \multirow[t]{2}{*}{ Lagged SUR } & & & {$[-0.00]$} & 0.000 & {$[-0.00]$} & {$[0.00]$} & {$[-0.00]$} & 0.003 & 0.003 \\
\hline & & & {$[-1.85]$} & {$[0.12]$} & {$[-1.21]$} & {$[0.97]$} & {$[-0.93]$} & {$[0.83]$} & {$[0.74]$} \\
\hline \multirow[t]{2}{*}{ Size } & -0.008 & -0.004 & -0.008 & {$[-0.01]$} & {$[-0.01]$} & -0.040 & -0.034 & {$[-0.00]$} & {$[-0.00]$} \\
\hline & {$[-3.19]$} & {$[-1.94]$} & {$[-3.62]$} & {$[-2.94]$} & {$[-2.22]$} & {$[-3.68]$} & {$[-3.36]$} & {$[-1.31]$} & {$[-1.15]$} \\
\hline \multirow[t]{2}{*}{$\mathrm{BE} / \mathrm{ME}$} & 0.009 & -0.003 & -0.001 & {$[0.01]$} & {$[0.00]$} & 0.021 & 0.008 & {$[0.01]$} & {$[0.00]$} \\
\hline & [2.05] & {$[-0.68]$} & {$[-0.36]$} & [2.39] & {$[0.49]$} & {$[2.47]$} & [0.99] & [1.66] & {$[0.12]$} \\
\hline \multirow[t]{2}{*}{ PastReturn } & -0.028 & -0.036 & -0.034 & {$[-0.04]$} & {$[-0.04]$} & -0.073 & -0.071 & {$[-0.07]$} & {$[-0.08]$} \\
\hline & {$[-0.84]$} & {$[-1.15]$} & {$[-1.07]$} & {$[-1.10]$} & {$[-1.36]$} & {$[-1.97]$} & {$[-2.06]$} & {$[-1.22]$} & {$[-1.72]$} \\
\hline Adj (Average) $\mathrm{R}^{2}$ & $4.99 \%$ & $13.86 \%$ & $4.46 \%$ & $5.16 \%$ & $19.41 \%$ & $8.64 \%$ & $21.74 \%$ & $26.54 \%$ & $42.85 \%$ \\
\hline Fixed Effect & $\mathrm{N}$ & $\mathrm{N}$ & $\mathrm{N}$ & $\mathrm{N}$ & $\mathrm{N}$ & Time+Firm & Time+Firm & Fama-MacBeth & Fama-MacBeth \\
\hline
\end{tabular}




\section{Table 8: Regressions of Discretionary Accruals}

This table examines managers' private information and discretionary accruals. Each quarter, discretionary accruals are estimated from the modified Jones model that includes book-to-market ratio and cash flow from operation (Lacker and Richardson, 2004), using a crosssectional regression. Meet is a dummy variable that takes one if a firm has earnings that were within plus or minus half-a-cent of the consensus forecast, and zero otherwise. Beat is a dummy variable that takes one if a firm has reported earnings between half-a-cent and one-and-a-half cents above the consensus forecast, and zero otherwise. Miss is a dummy variable that takes one if a firm has reported earnings between half-a-cent and one-and-a-half cents below the consensus forecast, and zero otherwise. The PQS is obtained from the RTCS for the period beginning after the fiscal-quarter- $t$ end and ending prior to the announcement date for quarter- $t$ earnings, and used as a proxy for managements' private information on the revenue for the fiscal quarter $t+1$. The SUE is estimated as $\left(A E_{i, t}-F_{i, t}\right) / P_{i, t}, w h e r e$ $A E_{i, t}$ is quarterly earnings per share announced for quarter $t$ of stock $i, F_{i, t}$ is mean analysts' forecasted EPS, and $P_{i, t}$ is quarter-end price. The SUR for stock $i$ in quarter $t$ is calculated as $\left[\left(S_{i, t}-S_{i, t-4}\right)-r_{i, t}\right] / \sigma_{i, t}$ where $\sigma_{i, t}$ and $r_{i, t}$ are the standard deviation and average, respectively, of $\left(\mathrm{S}_{\mathrm{i}, \mathrm{t}}-\mathrm{S}_{\mathrm{i},-\mathrm{-}-}\right)$ over the preceding eight quarters. Adjusted $\mathrm{R}^{2}$ (for pooled regressions) and the average $\mathrm{R}^{2}$ (for Fama-MacBeth regressions) are reported. The sample includes firm-quarters of US retailers with fiscal quarter ending between March 2009 and July 2014.

Panel A: Regressions on PQS

\begin{tabular}{|c|c|c|c|c|c|c|c|c|}
\hline Variables\Models & (1) & (2) & (3) & (4) & (5) & (6) & (7) & (8) \\
\hline \multirow[t]{2}{*}{ WQS } & 0.002 & & 0.003 & 0.002 & 0.002 & 0.004 & 0.006 & 0.001 \\
\hline & {$[0.93]$} & & {$[1.20]$} & {$[0.61]$} & {$[0.59]$} & [1.09] & [1.74] & [0.37] \\
\hline \multirow[t]{2}{*}{ PQS } & & 0.000 & -0.001 & -0.001 & -0.001 & -0.002 & -0.002 & 0.002 \\
\hline & & {$[-0.02]$} & {$[-0.61]$} & {$[-0.61]$} & {$[-0.62]$} & {$[-0.64]$} & {$[-0.59]$} & {$[0.97]$} \\
\hline \multirow[t]{2}{*}{ SUE } & & & & 0.314 & 0.307 & 0.331 & 0.338 & 0.310 \\
\hline & & & & {$[3.24]$} & {$[3.16]$} & {$[3.23]$} & [3.13] & {$[0.95]$} \\
\hline \multirow[t]{2}{*}{ Lagged SUE } & & & & & -0.065 & & & \\
\hline & & & & & {$[-1.05]$} & & & \\
\hline \multirow[t]{2}{*}{ SUR } & & & & 0.000 & 0.000 & 0.001 & 0.000 & 0.000 \\
\hline & & & & [1.18] & {$[1.21]$} & {$[1.45]$} & {$[-0.43]$} & {$[-0.13]$} \\
\hline \multirow[t]{2}{*}{ Lagged SUR } & & & & & 0.000 & & & \\
\hline & & & & & {$[0.01]$} & & & \\
\hline Adj (Average) $R^{2}$ & $-0.02 \%$ & $-0.15 \%$ & $-0.08 \%$ & $1.62 \%$ & $1.49 \%$ & $0.22 \%$ & $14.41 \%$ & $15.55 \%$ \\
\hline Fixed Effect & $\mathrm{N}$ & $\mathrm{N}$ & $\mathrm{N}$ & $\mathrm{N}$ & $\mathrm{N}$ & Time & Time + Firm & Fama-MacBeth \\
\hline \multicolumn{9}{|c|}{ Panel B: Regressions on the Beat, Meet, and Miss Dummies } \\
\hline Variables \Models & $(1)$ & $(2)$ & (3) & (4) & $(5)$ & $(6)$ & (7) & (8) \\
\hline \multirow[t]{2}{*}{ WQS } & 0.003 & 0.003 & 0.003 & 0.003 & 0.001 & 0.003 & 0.006 & 0.003 \\
\hline & {$[1.06]$} & [1.21] & {$[1.24]$} & [1.12] & {$[0.50]$} & {$[0.86]$} & {$[1.65]$} & {$[0.78]$} \\
\hline \multirow[t]{2}{*}{ PQS } & -0.002 & -0.001 & 0.000 & -0.001 & -0.001 & -0.001 & -0.001 & 0.005 \\
\hline & {$[-0.87]$} & {$[-0.60]$} & {$[-0.19]$} & {$[-0.42]$} & {$[-0.43]$} & {$[-0.48]$} & {$[-0.47]$} & [1.35] \\
\hline \multirow[t]{2}{*}{ Beat } & 0.003 & & & 0.003 & 0.003 & 0.004 & 0.002 & 0.005 \\
\hline & [1.96] & & & [1.82] & [1.98] & [2.14] & [1.13] & [2.75] \\
\hline \multirow[t]{2}{*}{ Meet } & & 0.001 & & 0.001 & 0.001 & 0.001 & -0.001 & -0.028 \\
\hline & & [0.38] & & {$[0.44]$} & [0.49] & [0.59] & {$[-0.32]$} & {$[-1.11]$} \\
\hline \multirow{2}{*}{ Miss } & & & -0.005 & -0.004 & -0.004 & -0.004 & -0.006 & 0.103 \\
\hline & & & {$[-1.81]$} & {$[-1.61]$} & {$[-1.51]$} & {$[-1.64]$} & {$[-2.29]$} & {$[0.96]$} \\
\hline \multirow[t]{2}{*}{ Beat $\times$ PQS } & 0.008 & & & 0.007 & 0.007 & 0.008 & 0.005 & -0.038 \\
\hline & [1.27] & & & [1.08] & [1.11] & [1.19] & [0.81] & {$[-0.66]$} \\
\hline \multirow[t]{2}{*}{ Meet $\times$ PQS } & & -0.001 & & -0.001 & 0.000 & 0.000 & 0.002 & -0.280 \\
\hline & & {$[-0.10]$} & & {$[-0.12]$} & {$[-0.01]$} & {$[-0.02]$} & {$[0.28]$} & {$[-1.00]$} \\
\hline \multirow[t]{2}{*}{ Miss $\times$ PQS } & & & -0.017 & -0.016 & -0.016 & -0.014 & -0.011 & 0.483 \\
\hline & & & {$[-1.74]$} & {$[-1.65]$} & {$[-1.69]$} & {$[-1.39]$} & {$[-1.14]$} & [0.96] \\
\hline \multirow[t]{2}{*}{ SUE } & & & & & 0.315 & 0.338 & 0.334 & 0.155 \\
\hline & & & & & [3.24] & [3.31] & [3.09] & [0.49] \\
\hline \multirow[t]{2}{*}{ SUR } & & & & & 0.000 & 0.001 & 0.000 & 0.000 \\
\hline & & & & & {$[1.22]$} & {$[1.43]$} & {$[-0.32]$} & {$[-0.24]$} \\
\hline Adj (Average) $R^{2}$ & $0.42 \%$ & $-0.35 \%$ & $0.84 \%$ & $0.92 \%$ & $2.73 \%$ & $1.45 \%$ & $15.21 \%$ & $38.28 \%$ \\
\hline Fixed Effect & $\mathrm{N}$ & $\mathrm{N}$ & $\mathrm{N}$ & $\mathrm{N}$ & $\mathrm{N}$ & Time & Time + Firm & Fama-MacBeth \\
\hline
\end{tabular}




\section{Table 9: Bundled Management Forecasts}

This table investigates the relation between managements' forecasts issued around earnings announcement dates and their private information, proxied by PQS. The dependent variable is a dummy variable equal to one if the management forecast is pessimistic compared to realized earnings (or revenue) and zero otherwise. We assume the management forecast to be pessimistic if the related management forecast error is less than a cutoff value. The management forecasting error is defined as $\left(\mathrm{MF}_{i t+1}-A_{i t+1}\right)$ scaled by $P_{i t+1}$ for $E P S$, or by $M F_{i t+1}$ for revenue, where $M F_{i t+1}$ is the management forecast for quarterly EPS or for revenue of quarter $t+1$, and $A_{i, t+1}$ is realized quarterly EPS or revenue amount. Panel A uses management forecasts of EPS, while Panel B makes use of revenue forecasts of managements. The PQS is obtained from the RTCS for the period beginning after the fiscal-quarter-t end and ending prior to the announcement date for quarter- $t$ earnings, and used as a proxy for managements' private information on the revenue for the fiscal quarter $t+1$. The SUE is estimated as $\left(\mathrm{AE}_{\mathrm{i}, \mathrm{t}}-\mathrm{FE}_{\mathrm{i}, \mathrm{t}}\right) / \mathrm{P}_{\mathrm{i}, \mathrm{t}}$, where $\mathrm{AE}_{\mathrm{i}, \mathrm{t}}$ is quarterly earnings per share announced for quarter $t$ of stock $\mathrm{i}, \mathrm{FE}, \mathrm{i}, \mathrm{is}$ mean analysts' forecasted EPS, and $\mathrm{P}_{\mathrm{i}, \mathrm{t}}$ is quarter-end price. The $\mathrm{SUR}$ for stock $i$ in quarter $t$ is calculated as $\left[\left(\mathrm{S}_{\mathrm{i}, \mathrm{t}}-\mathrm{S}_{\mathrm{i}, \mathrm{t}-\mathrm{A}}\right)-\mathrm{r}_{\mathrm{i}, \mathrm{t}}\right] / \sigma_{\mathrm{i}, \mathrm{t}}$ where $\sigma_{\mathrm{i}, \mathrm{t}}$ and $\mathrm{r}_{\mathrm{i}, \mathrm{t}}$ are the standard deviation and average, respectively, of $\left(\mathrm{S}_{\mathrm{i}, \mathrm{t}}-\mathrm{S}_{\mathrm{i}, \mathrm{t}-\mathrm{a}}\right)$ over the preceding eight quarters. Panel $\mathrm{B}$ uses analysts' forecast errors for revenue, $A F E$, as an explanatory variable. AFE is computed as $\left(A R_{i, t}-F R_{i, t}\right) / F R_{i, t}$, where $A R_{i, t}$ is quarterly sales amount announced for quarter $t$ of stock $i$, and $F R_{i, t}$ is mean analysts' forecast for quarterly sales. Size is the natural logarithm of the market capitalization as of fiscal quarter-t end. BE/ME is the natural logarithm of the book-to-market ratio as of the most recent fiscal year ending at least three month prior to fiscal quarter- $t$ end. Return $(4,60)$ is the cumulative return in excess over the market for the period between four days and 60 days post the earnings announcement. We report the marginal probability change that sample consists of the firm-quarters of companies which provided forecasts for the next quarter EPS on or within three days after the earnings announcement dates.

\begin{tabular}{|c|c|c|c|c|c|c|c|c|c|c|c|c|}
\hline \multirow{2}{*}{$\begin{array}{c}\text { Model } \\
\text { Variable }\end{array}$} & \multicolumn{2}{|c|}{ (1) } & \multicolumn{2}{|c|}{ (2) } & \multicolumn{2}{|c|}{ (3) } & \multicolumn{2}{|c|}{ (4) } & \multicolumn{2}{|c|}{ (5) } & \multicolumn{2}{|c|}{ (6) } \\
\hline & Coefficient & Marg. Prob & Coefficient & Marg. Prob & Coefficient & Marg. Prob & Coefficient & Marg. Prob & Coefficient & Marg. Prob & Coefficient & Marg. Prob \\
\hline PQS & 0.479 & $5.12 \%$ & 0.667 & $6.55 \%$ & 0.628 & $6.15 \%$ & 0.814 & $7.63 \%$ & 0.746 & $6.66 \%$ & 0.601 & $5.12 \%$ \\
\hline SUE $\times 100$ & [1.77] & & $\begin{array}{l}{[2.30]} \\
3.329 \\
{[5.16]}\end{array}$ & $16.70 \%$ & $\begin{array}{l}{[2.16]} \\
3.219 \\
{[4.98]}\end{array}$ & $16.09 \%$ & $\begin{array}{l}{[2.31]} \\
3.306 \\
{[5.03]}\end{array}$ & $16.41 \%$ & $\begin{array}{l}{[2.09]} \\
3.010 \\
{[4.32]}\end{array}$ & $14.26 \%$ & $\begin{array}{l}{[1.64]} \\
3.213 \\
{[4.47]}\end{array}$ & $14.75 \%$ \\
\hline SUR & & & & & $\begin{array}{l}0.068 \\
{[1.33]}\end{array}$ & $3.61 \%$ & $\begin{array}{l}0.077 \\
{[1.47]}\end{array}$ & $3.93 \%$ & $\begin{array}{l}0.095 \\
{[1.76]}\end{array}$ & $4.67 \%$ & $\begin{array}{l}0.082 \\
{[1.49]}\end{array}$ & $3.89 \%$ \\
\hline WQS & & & & & & & $\begin{array}{l}-0.422 \\
{[-0.96]}\end{array}$ & $-2.66 \%$ & $\begin{array}{l}-0.398 \\
{[-0.89]}\end{array}$ & $-2.37 \%$ & $\begin{array}{l}-0.336 \\
{[-0.74]}\end{array}$ & $-1.85 \%$ \\
\hline Size & & & & & & & & & $\begin{array}{l}-0.223 \\
{[-3.20]}\end{array}$ & $-9.80 \%$ & $\begin{array}{l}-0.222 \\
{[-3.14]}\end{array}$ & $-9.43 \%$ \\
\hline $\mathrm{BE} / \mathrm{ME}$ & & & & & & & & & $\begin{array}{l}-0.234 \\
{[-1.63]}\end{array}$ & $-4.40 \%$ & $\begin{array}{l}-0.265 \\
{[-1.82]}\end{array}$ & $-4.82 \%$ \\
\hline $\operatorname{Ret}(4,60)$ & & & & & & & & & & & $\begin{array}{l}2.492 \\
{[3.19]}\end{array}$ & $8.64 \%$ \\
\hline Pseudo $\mathrm{R}^{2}$ & $0.81 \%$ & & $8.93 \%$ & & $9.37 \%$ & & $9.60 \%$ & & $12.75 \%$ & & $15.40 \%$ & \\
\hline \multicolumn{13}{|c|}{ Panel B: Management Forecasts on Revenue } \\
\hline \multirow{2}{*}{$\begin{array}{c}\text { Model } \\
\text { Variable }\end{array}$} & \multicolumn{2}{|c|}{ (1) } & \multicolumn{2}{|c|}{ (2) } & \multicolumn{2}{|c|}{ (3) } & \multicolumn{2}{|c|}{ (4) } & \multicolumn{2}{|c|}{ (5) } & \multicolumn{2}{|c|}{ (6) } \\
\hline & Coefficient & Marg. Prob & Coefficient & Marg. Prob & Coefficient & Marg. Prob & Coefficient & Marg. Prob & Coefficient & Marg. Prob & Coefficient & Marg. Prob \\
\hline PQS & $\begin{array}{l}0.785 \\
{[1.70]}\end{array}$ & $6.34 \%$ & $\begin{array}{l}0.998 \\
{[2.08]}\end{array}$ & $7.30 \%$ & $\begin{array}{l}1.062 \\
{[2.16]}\end{array}$ & $7.81 \%$ & $\begin{array}{l}1.127 \\
{[1.97]}\end{array}$ & $8.47 \%$ & $\begin{array}{l}1.050 \\
{[1.80]}\end{array}$ & $7.91 \%$ & $\begin{array}{l}1.001 \\
{[1.69]}\end{array}$ & $7.16 \%$ \\
\hline AFE & & & $\begin{array}{l}22.114 \\
{[4.38]}\end{array}$ & $18.25 \%$ & $\begin{array}{c}20.337 \\
{[3.81]}\end{array}$ & $16.81 \%$ & $\begin{array}{r}20.457 \\
{[3.81]}\end{array}$ & $16.94 \%$ & $\begin{array}{c}20.673 \\
{[3.80]}\end{array}$ & $17.00 \%$ & $\begin{array}{c}23.495 \\
{[4.19]}\end{array}$ & $18.31 \%$ \\
\hline SUE $\times 100$ & & & & & $\begin{array}{l}0.310 \\
{[0.44]}\end{array}$ & $1.72 \%$ & $\begin{array}{l}0.298 \\
{[0.43]}\end{array}$ & $1.62 \%$ & $\begin{array}{l}0.692 \\
{[0.84]}\end{array}$ & $3.76 \%$ & $\begin{array}{l}0.539 \\
{[0.66]}\end{array}$ & $2.77 \%$ \\
\hline WQS & & & & & & & $\begin{array}{l}-0.132 \\
{[-0.22]}\end{array}$ & $-1.25 \%$ & $\begin{array}{l}-0.105 \\
{[-0.17]}\end{array}$ & $-1.17 \%$ & $\begin{array}{l}-0.066 \\
{[-0.11]}\end{array}$ & $-0.84 \%$ \\
\hline Size & & & & & & & & & $\begin{array}{l}0.058 \\
{[0.56]}\end{array}$ & $2.32 \%$ & $\begin{array}{l}0.035 \\
{[0.33]}\end{array}$ & $1.31 \%$ \\
\hline $\mathrm{BE} / \mathrm{ME}$ & & & & & & & & & $\begin{array}{l}-0.213 \\
{[-1.24]}\end{array}$ & $-4.50 \%$ & $\begin{array}{l}-0.289 \\
{[-1.63]}\end{array}$ & $-5.77 \%$ \\
\hline $\operatorname{Ret}(4,60)$ & & & & & & & & & & & $\begin{array}{l}2.713 \\
{[3.02]}\end{array}$ & $10.25 \%$ \\
\hline Pseudo $\mathrm{R}^{2}$ & $1.15 \%$ & & $10.04 \%$ & & $9.72 \%$ & & $9.74 \%$ & & $10.64 \%$ & & $14.42 \%$ & \\
\hline
\end{tabular}




\section{Table 10: Managerial Tones in Conference Calls}

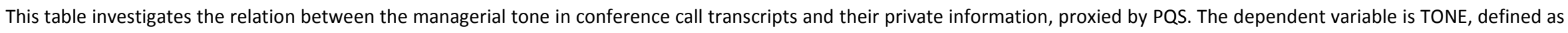
$\log (1+$ number of positive words) minus log $(1+$ number of positive words + number of negative words). We use the list of positive and negative words from Loughran and McDonald (2011). The PQS is obtained from the RTCS for the period beginning after the fiscal-quarter- $t$ end and ending prior to the announcement date for quarter- $t$ earnings, and used as a proxy

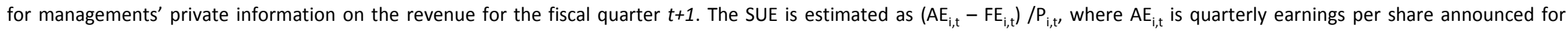
quarter $t$ of stock $\mathrm{i}, \mathrm{FE}_{\mathrm{i}, \mathrm{t}}$ is mean analysts' forecasted EPS, and $\mathrm{P}_{\mathrm{i}, \mathrm{t}}$ is quarter-end price. The SUR for stock $i$ in quarter $t$ is calculated as $\left[\left(\mathrm{S}_{\mathrm{i}, \mathrm{t}}-\mathrm{S}_{\mathrm{i}, \mathrm{t}-\mathrm{i}}\right)-\mathrm{r}_{\mathrm{i}, \mathrm{t}}\right] / \sigma_{\mathrm{i}, \mathrm{t}}$ where $\sigma_{\mathrm{i}, \mathrm{t}}$ and $\mathrm{r}_{\mathrm{i}, \mathrm{t}}$ are the standard deviation and average, respectively, of $\left(\mathrm{S}_{\mathrm{i}, \mathrm{t}}-\mathrm{S}_{\mathrm{i}, \mathrm{t}-\mathrm{t}}\right)$ over the preceding eight quarters. Size is the natural logarithm of the market capitalization as of fiscal quarter- $t$ end. $\mathrm{BE} / \mathrm{ME}$ is

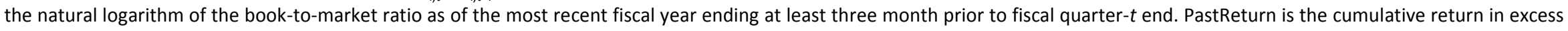
over the market from thirty to three days prior to the earnings announcement. Adjusted $\mathrm{R}^{2}$ are reported. The sample includes firm-quarters of US retailers with fiscal quarter ending between March 2009 and July 2014.

\begin{tabular}{|c|c|c|c|c|c|c|c|c|c|}
\hline Variables\Models & (1) & (2) & (3) & (4) & (5) & (6) & (7) & (8) & (9) \\
\hline \multirow[t]{2}{*}{ PQS } & -0.050 & -0.053 & -0.055 & -0.054 & -0.055 & -0.045 & -0.053 & -0.036 & -0.042 \\
\hline & {$[-1.92]$} & {$[-2.05]$} & {$[-2.05]$} & {$[-2.91]$} & {$[-2.86]$} & {$[-1.85]$} & {$[-2.08]$} & {$[-1.78]$} & {$[-1.98]$} \\
\hline \multirow[t]{2}{*}{ WQS } & 0.072 & 0.040 & 0.038 & 0.018 & 0.028 & 0.039 & 0.037 & 0.002 & 0.013 \\
\hline & {$[2.22]$} & {$[1.20]$} & {$[1.08]$} & {$[0.75]$} & {$[1.16]$} & [1.09] & [1.02] & {$[0.08]$} & {$[0.45]$} \\
\hline \multirow[t]{2}{*}{ SUE } & & 0.180 & 0.610 & 0.751 & 0.341 & 0.636 & 0.980 & 1.083 & 0.666 \\
\hline & & {$[0.16]$} & {$[0.51]$} & [0.87] & {$[0.37]$} & [0.49] & {$[0.71]$} & [1.22] & {$[0.70]$} \\
\hline \multirow[t]{2}{*}{ Lagged SUE } & & & -1.017 & & -0.123 & & -0.775 & & 0.144 \\
\hline & & & {$[-1.15]$} & & {$[-0.18]$} & & {$[-1.84]$} & & {$[0.21]$} \\
\hline \multirow[t]{2}{*}{ SUR } & & 0.015 & 0.013 & 0.007 & 0.008 & 0.015 & 0.015 & 0.007 & 0.008 \\
\hline & & {$[4.38]$} & [3.39] & [2.69] & {$[2.47]$} & [3.90] & [3.98] & [2.34] & [2.39] \\
\hline \multirow[t]{2}{*}{ Lagged SUR } & & & 0.005 & & 0.000 & & 0.001 & & -0.005 \\
\hline & & & {$[1.29]$} & & {$[-0.14]$} & & {$[0.26]$} & & [-1.37] \\
\hline \multirow[t]{2}{*}{ Accruals } & & & 0.105 & & 0.569 & & 0.161 & & 0.616 \\
\hline & & & {$[0.25]$} & & [1.77] & & {$[0.28]$} & & [1.95] \\
\hline \multirow[t]{2}{*}{ Size } & & 0.025 & 0.026 & 0.052 & 0.048 & 0.025 & 0.026 & 0.017 & 0.015 \\
\hline & & [5.19] & [5.21] & [3.23] & [2.90] & [1.90] & [1.91] & [0.93] & [0.78] \\
\hline \multirow[t]{2}{*}{$\mathrm{BE} / \mathrm{ME}$} & & -0.030 & -0.034 & 0.015 & 0.013 & -0.032 & -0.039 & 0.032 & 0.028 \\
\hline & & {$[-2.67]$} & {$[-2.96]$} & [1.21] & [0.98] & {$[-1.45]$} & {$[-1.68]$} & [2.12] & [1.68] \\
\hline \multirow[t]{2}{*}{ Past Return } & & -0.034 & -0.053 & -0.025 & -0.026 & -0.018 & -0.029 & -0.020 & -0.014 \\
\hline & & {$[-0.54]$} & {$[-0.80]$} & {$[-0.51]$} & {$[-0.50]$} & {$[-0.30]$} & {$[-0.45]$} & {$[-0.41]$} & {$[-0.26]$} \\
\hline $\operatorname{Adj~} R^{2}$ & $0.75 \%$ & $10.05 \%$ & $10.84 \%$ & $57.22 \%$ & $58.18 \%$ & $10.45 \%$ & $10.32 \%$ & $60.36 \%$ & $61.04 \%$ \\
\hline Fixed Effect & $\mathrm{N}$ & $\mathrm{N}$ & $\mathrm{N}$ & Firm & Firm & Time & Time & Time + Firm & Time + Firm \\
\hline
\end{tabular}


This table investigates the insiders' trading activities around earnings announcements and the private information. Panel A shows the frequency of insider trades as a percentage of the number of earnings announcements. Earnings announcements are grouped based on PQS quartiles and the signs of announcement returns. Quartiles of PQS are calculated every quarter. Panel B shows the regression results of the announcement returns on insider trading variables and their interaction terms with PQS. Panel $\mathrm{C}$ reports the regression results of post-earnings announcement returns over various holding periods. The PQS is obtained from the RTCS for the period beginning after the fiscal-quarter-t end and ending prior to the announcement date for quarter-t earnings, and used as a proxy for managements' private information on the revenue for the fiscal quarter $t+1$. Buy is an indicator variable that equals one if management team is a net buyer during the 20 trading day period following earnings announcement, and zero otherwise. Sell is an indicator variable that equals one if management team is a net seller, and zero otherwise. The SUE is estimated as $\left(A E_{i, t}-F_{i, t}\right) / P_{i, t}$, where $A E_{i, t}$ is quarterly earnings per share announced for quarter $t$ of stock $\mathrm{i}, \mathrm{FE}_{\mathrm{i}, \mathrm{t}}$ is mean analysts' forecasted EPS, and $\mathrm{P}_{\mathrm{i}, \mathrm{t}}$ is quarter-end price. The SUR for stock $i$ in quarter $t$ is calculated as $\left[\left(\mathrm{S}_{\mathrm{i}, \mathrm{t}}-\mathrm{S}_{\mathrm{i}, \mathrm{t}-\mathrm{-}}\right)-\mathrm{r}_{\mathrm{i}, \mathrm{t}}\right] / \sigma_{\mathrm{i}, \mathrm{t}}$ where $\sigma_{\mathrm{i}, \mathrm{t}}$ and $\mathrm{r}_{\mathrm{i}, \mathrm{t}}$ are the standard deviation and average, respectively, of $\left(\mathrm{S}_{\mathrm{i}, \mathrm{t}}-\mathrm{S}_{\mathrm{i}, \mathrm{t}-\mathrm{t}}\right)$ over the preceding eight quarters. The DA is discretionary accrual estimated using the modified Jones model, by estimating a cross-section regression each quarter. Size is the natural logarithm of the market capitalization as of fiscal quarter- $t$ end. BE/ME is the natural logarithm of the book-to-market ratio as of the most recent fiscal year ending at least three month prior to fiscal quarter-t end. PastReturn is the cumulative return in excess over the market from thirty to three days prior to the earnings announcement. Standard errors are clustered at firm level. Adjusted $\mathrm{R}^{2}$ are reported. The sample includes firmquarters of US retailers with fiscal quarter ending between March 2009 and July 2014.

Panel A: Summary Statistics of Insider Trading

\begin{tabular}{|c|c|c|c|c|c|c|}
\hline \multirow{3}{*}{$\begin{array}{c}\text { PQS } \\
\text { Quartile }\end{array}$} & \multirow{3}{*}{$\begin{array}{c}\text { Sign of } \\
\text { Announcement } \\
\text { Return }\end{array}$} & \multirow{3}{*}{$\begin{array}{c}\text { Number } \\
\text { of } \\
\text { Announcements }\end{array}$} & \multicolumn{2}{|c|}{ Freqeuncy: Insider Buy } & \multicolumn{2}{|c|}{ Frequency: Insider Sell } \\
\hline & & & $\%$ of Number of & $\%$ of Total & $\%$ of Number of & $\%$ of Total \\
\hline & & & Announcement & Number of Buy & Announcement & Number of Sell \\
\hline \multirow[t]{2}{*}{$1 Q$} & - & 96 & $2 \%$ & $12 \%$ & $29 \%$ & $11 \%$ \\
\hline & + & 100 & $3 \%$ & $19 \%$ & $31 \%$ & $12 \%$ \\
\hline \multirow[t]{2}{*}{$2 \mathrm{Q}$ and $3 \mathrm{Q}$} & - & 204 & $1 \%$ & $19 \%$ & $25 \%$ & $20 \%$ \\
\hline & + & 222 & $1 \%$ & $19 \%$ & $37 \%$ & $33 \%$ \\
\hline \multirow[t]{2}{*}{$4 Q$} & - & 91 & $4 \%$ & $25 \%$ & $22 \%$ & $8 \%$ \\
\hline & + & 104 & $1 \%$ & $6 \%$ & $40 \%$ & $17 \%$ \\
\hline
\end{tabular}

Panel B: Regressions of Announcement Returns

\begin{tabular}{|c|c|c|c|c|c|c|}
\hline Variables\Models & (1) & (2) & (3) & (4) & (5) & (6) \\
\hline \multirow[t]{2}{*}{ WQS } & 0.077 & 0.050 & 0.076 & 0.046 & 0.076 & 0.046 \\
\hline & [4.53] & {$[3.11]$} & [3.69] & {$[2.39]$} & {$[2.72]$} & {$[2.04]$} \\
\hline \multirow[t]{2}{*}{ PQS } & -0.036 & -0.039 & -0.020 & -0.023 & -0.020 & -0.023 \\
\hline & {$[-2.19]$} & {$[-2.56]$} & {$[-1.07]$} & {$[-1.34]$} & {$[-1.18]$} & {$[-1.28]$} \\
\hline \multirow[t]{2}{*}{ Buy } & -0.044 & -0.030 & -0.047 & -0.034 & -0.047 & -0.034 \\
\hline & {$[-1.89]$} & {$[-1.39]$} & {$[-1.99]$} & {$[-1.55]$} & {$[-1.42]$} & {$[-1.00]$} \\
\hline \multirow[t]{2}{*}{ Sell } & 0.028 & 0.022 & 0.027 & 0.022 & 0.027 & 0.022 \\
\hline & [3.74] & [3.23] & [3.67] & [3.09] & [3.85] & {$[3.25]$} \\
\hline \multirow[t]{2}{*}{ Buy $\times$ PQS } & -0.260 & -0.264 & -0.283 & -0.276 & -0.283 & -0.276 \\
\hline & {$[-1.95]$} & {$[-2.14]$} & {$[-2.10]$} & {$[-2.20]$} & {$[-1.56]$} & {$[-1.50]$} \\
\hline \multirow[t]{2}{*}{ Sell $\times$ PQS } & 0.007 & 0.013 & -0.005 & 0.002 & -0.005 & 0.002 \\
\hline & {$[0.26]$} & {$[0.54]$} & {$[-0.18]$} & {$[0.07]$} & {$[-0.24]$} & [0.09] \\
\hline \multirow[t]{2}{*}{ DA } & 0.533 & 0.195 & 0.525 & 0.186 & 0.525 & 0.186 \\
\hline & {$[2.29]$} & {$[0.89]$} & {$[2.26]$} & {$[0.85]$} & {$[1.52]$} & {$[0.52]$} \\
\hline \multirow[t]{2}{*}{ SUE } & & 5.177 & & 4.977 & & 4.977 \\
\hline & & [9.41] & & [8.72] & & {$[6.07]$} \\
\hline \multirow[t]{2}{*}{ Lagged SUE } & -0.728 & -0.658 & -0.657 & -0.597 & -0.657 & -0.597 \\
\hline & {$[-1.95]$} & {$[-1.90]$} & {$[-1.70]$} & {$[-1.67]$} & {$[-1.59]$} & {$[-1.19]$} \\
\hline \multirow[t]{2}{*}{ SUR } & & 0.007 & & 0.008 & & 0.008 \\
\hline & & [3.14] & & [3.50] & & {$[3.37]$} \\
\hline \multirow[t]{2}{*}{ Lagged SUR } & -0.002 & -0.004 & 0.001 & -0.003 & 0.001 & -0.004 \\
\hline & {$[-0.98]$} & {$[-1.82]$} & {$[0.26]$} & {$[-1.42]$} & {$[0.32]$} & {$[-2.12]$} \\
\hline \multirow[t]{2}{*}{ Size } & -0.007 & -0.005 & -0.006 & -0.004 & -0.006 & -0.004 \\
\hline & {$[-2.57]$} & {$[-1.96]$} & {$[-1.98]$} & {$[-1.67]$} & {$[-1.65]$} & {$[-1.66]$} \\
\hline \multirow[t]{2}{*}{$\mathrm{BE} / \mathrm{ME}$} & 0.016 & 0.005 & 0.020 & 0.009 & 0.020 & 0.009 \\
\hline & [3.05] & [1.06] & {$[3.46]$} & [1.70] & [2.39] & [1.98] \\
\hline \multirow[t]{2}{*}{ PastReturn } & -0.054 & -0.056 & -0.045 & -0.051 & -0.045 & -0.052 \\
\hline & {$[-1.44]$} & {$[-1.62]$} & {$[-1.14]$} & {$[-1.43]$} & {$[-0.81]$} & {$[-0.98]$} \\
\hline Adj (Average) $R^{2}$ & $8.55 \%$ & $21.49 \%$ & $9.74 \%$ & $22.22 \%$ & $9.74 \%$ & $22.22 \%$ \\
\hline Fixed Effect & $\mathrm{N}$ & $\mathrm{N}$ & Time & Time & Time & Time \\
\hline Standard Error & OLS & OLS & OLS & OLS & Clustered & Clustered \\
\hline
\end{tabular}


Panel C: Regressions of Post-Earnings-Announcement Returns

\begin{tabular}{|c|c|c|c|c|c|c|}
\hline \multirow{2}{*}{$\begin{array}{l}\text { Dependent Var } \\
\text { Variables } \backslash \text { Models }\end{array}$} & \multicolumn{2}{|c|}{$\operatorname{Ret}(4,60)$} & \multicolumn{2}{|c|}{$\operatorname{Ret}(4,20)$} & \multicolumn{2}{|c|}{$\operatorname{Ret}(21,60)$} \\
\hline & (1) & (2) & (1) & (2) & (1) & (2) \\
\hline \multirow[t]{2}{*}{ WQS } & 0.041 & 0.010 & 0.013 & -0.006 & 0.029 & 0.018 \\
\hline & {$[1.66]$} & {$[0.28]$} & [1.03] & {$[-0.43]$} & [1.39] & {$[0.68]$} \\
\hline \multirow[t]{2}{*}{ PQS } & 0.025 & 0.048 & -0.005 & 0.006 & 0.031 & 0.040 \\
\hline & [1.10] & [1.94] & {$[-0.44]$} & [0.54] & [1.38] & [1.57] \\
\hline \multirow[t]{2}{*}{ Buy } & -0.010 & -0.014 & 0.035 & 0.027 & -0.050 & -0.045 \\
\hline & {$[-0.28]$} & {$[-0.50]$} & {$[3.41]$} & {$[2.20]$} & {$[-1.68]$} & {$[-1.87]$} \\
\hline \multirow[t]{2}{*}{ Sell } & -0.003 & -0.005 & 0.000 & 0.001 & 0.000 & -0.002 \\
\hline & {$[-0.24]$} & {$[-0.47]$} & {$[0.06]$} & {$[0.15]$} & {$[-0.02]$} & {$[-0.24]$} \\
\hline \multirow[t]{2}{*}{ Buy $\times$ PQS } & 0.410 & 0.311 & 0.019 & -0.021 & 0.310 & 0.257 \\
\hline & {$[2.72]$} & [2.39] & {$[0.27]$} & {$[-0.31]$} & [1.92] & [1.83] \\
\hline \multirow[t]{2}{*}{ Sell × PQS } & 0.021 & -0.003 & 0.030 & 0.024 & -0.014 & -0.030 \\
\hline & {$[0.71]$} & {$[-0.10]$} & [2.57] & [1.89] & {$[-0.46]$} & {$[-1.12]$} \\
\hline \multirow[t]{2}{*}{ DA } & 0.408 & 0.475 & 0.277 & 0.287 & 0.081 & 0.134 \\
\hline & {$[0.88]$} & [1.01] & [1.43] & [1.69] & [0.19] & [0.32] \\
\hline \multirow[t]{2}{*}{ SUE } & 1.501 & 1.474 & 0.813 & 1.005 & 0.468 & 0.280 \\
\hline & {$[1.85]$} & {$[1.76]$} & {$[1.67]$} & {$[2.06]$} & {$[0.57]$} & {$[0.31]$} \\
\hline \multirow[t]{2}{*}{ Lagged SUE } & -0.725 & -0.551 & 0.774 & 0.556 & -1.679 & -1.314 \\
\hline & {$[-0.55]$} & {$[-0.45]$} & [2.68] & {$[2.34]$} & [-1.14] & {$[-0.96]$} \\
\hline \multirow[t]{2}{*}{ SUR } & 0.002 & -0.002 & 0.002 & 0.002 & 0.001 & -0.003 \\
\hline & {$[0.71]$} & {$[-0.63]$} & [1.94] & {$[1.44]$} & {$[0.31]$} & {$[-1.15]$} \\
\hline \multirow[t]{2}{*}{ Lagged SUR } & -0.007 & -0.004 & -0.003 & -0.004 & -0.005 & -0.001 \\
\hline & {$[-2.45]$} & {$[-1.02]$} & {$[-2.02]$} & {$[-2.83]$} & {$[-1.85]$} & {$[-0.25]$} \\
\hline \multirow[t]{2}{*}{ Size } & -0.005 & -0.003 & -0.001 & -0.001 & -0.003 & -0.001 \\
\hline & {$[-1.30]$} & {$[-0.85]$} & {$[-0.54]$} & {$[-0.66]$} & {$[-0.91]$} & {$[-0.25]$} \\
\hline \multirow[t]{2}{*}{$\mathrm{BE} / \mathrm{ME}$} & 0.022 & 0.022 & 0.005 & 0.005 & 0.015 & 0.015 \\
\hline & {$[2.82]$} & {$[2.33]$} & [1.64] & {$[1.45]$} & {$[2.12]$} & [1.87] \\
\hline \multirow[t]{2}{*}{ PastReturn } & -0.063 & -0.043 & -0.012 & -0.022 & -0.022 & 0.004 \\
\hline & {$[-0.74]$} & {$[-0.53]$} & {$[-0.45]$} & {$[-0.84]$} & {$[-0.30]$} & {$[0.06]$} \\
\hline Adj (Average) $R^{2}$ & $3.87 \%$ & $9.43 \%$ & $3.31 \%$ & $8.28 \%$ & $3.73 \%$ & $9.61 \%$ \\
\hline Fixed Effect & $\mathrm{N}$ & Time & $\mathrm{N}$ & Time & $\mathrm{N}$ & Time \\
\hline Standard Error & Clustered & Clustered & Clustered & Clustered & Clustered & Clustered \\
\hline
\end{tabular}




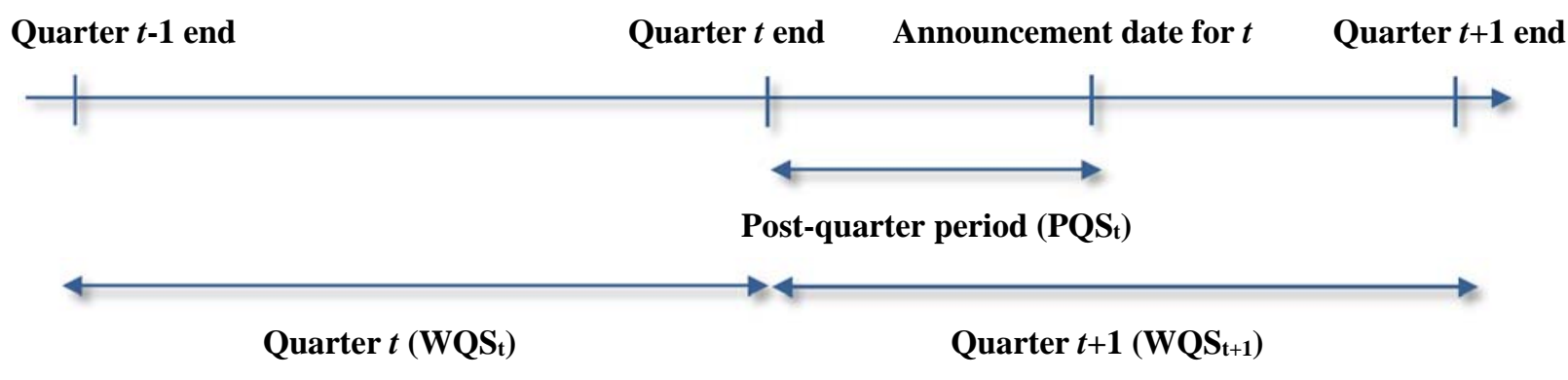

Figure 1 Time periods around earnings announcements and real-time corporate sales. The figure plots the time line around quarterly earnings announcements and describes the time periods for which real-time corporate sales (RTCS) is measured. WQS is within-quarter measure of RTCS, while PQS is RTCS measure for the post-quarter period. The post-quarter period is defined as the time period beginning the fiscal-quarter $t+1$ and ending prior to the announcement date for quarter- $t$ earnings. 
GAP

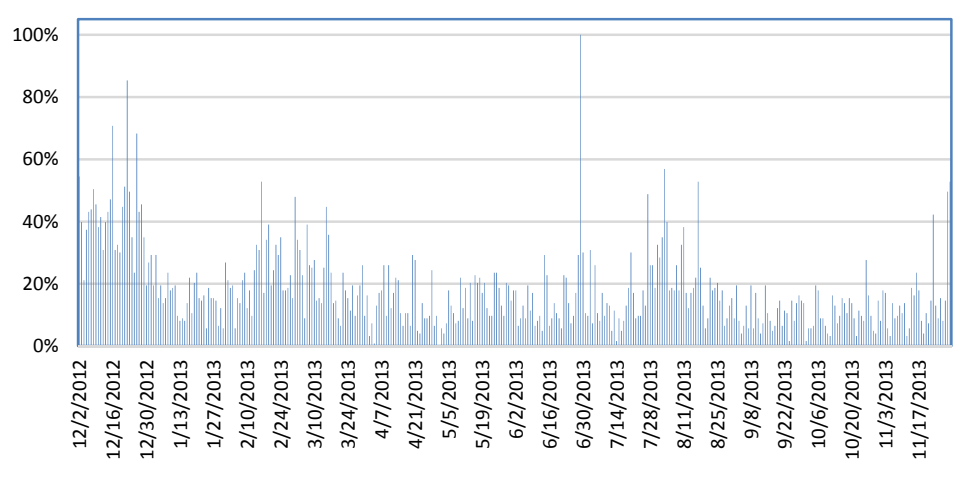

Target

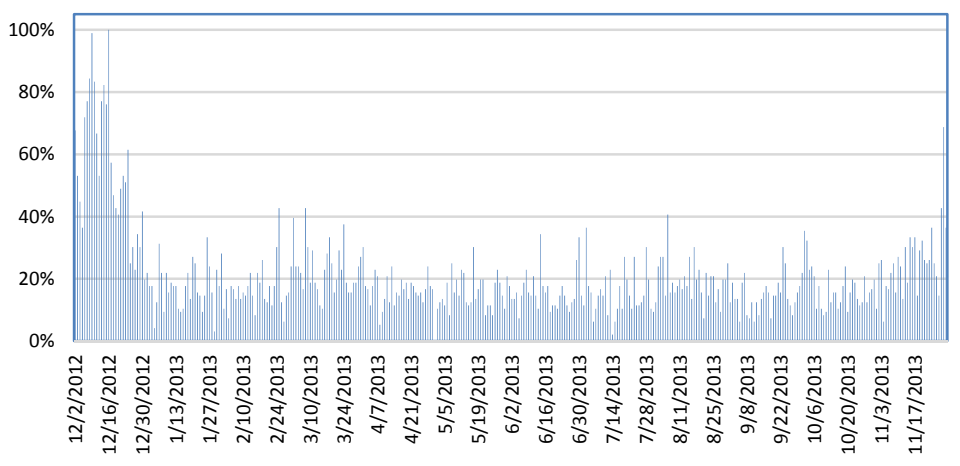

All

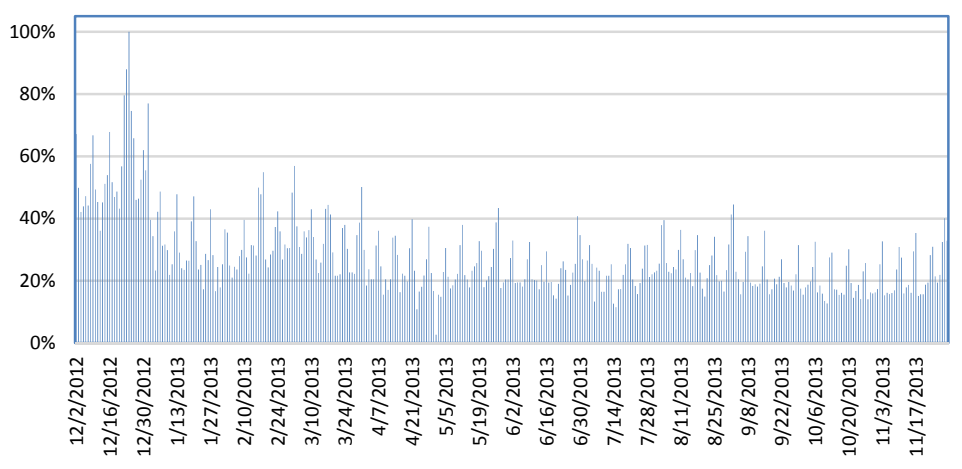

Figure 2. Daily time-series of consumer activities obtained from Android device. The figure plots one of the data sources that are used to construct the real-time corporate sales index. The first and second panels provide daily time series of consumer activities to GAP and Target Corp over the period of Dec. 2012 to Nov. 2013, while the third panel describes the consumer activities to all the firms in the sample. $y$-axis plots daily consumer activities, scaled by the highest value of daily activities during the time period. The highest value is set to $100 \%$. This data is extracted from Andoid mobile devices in the United States. 


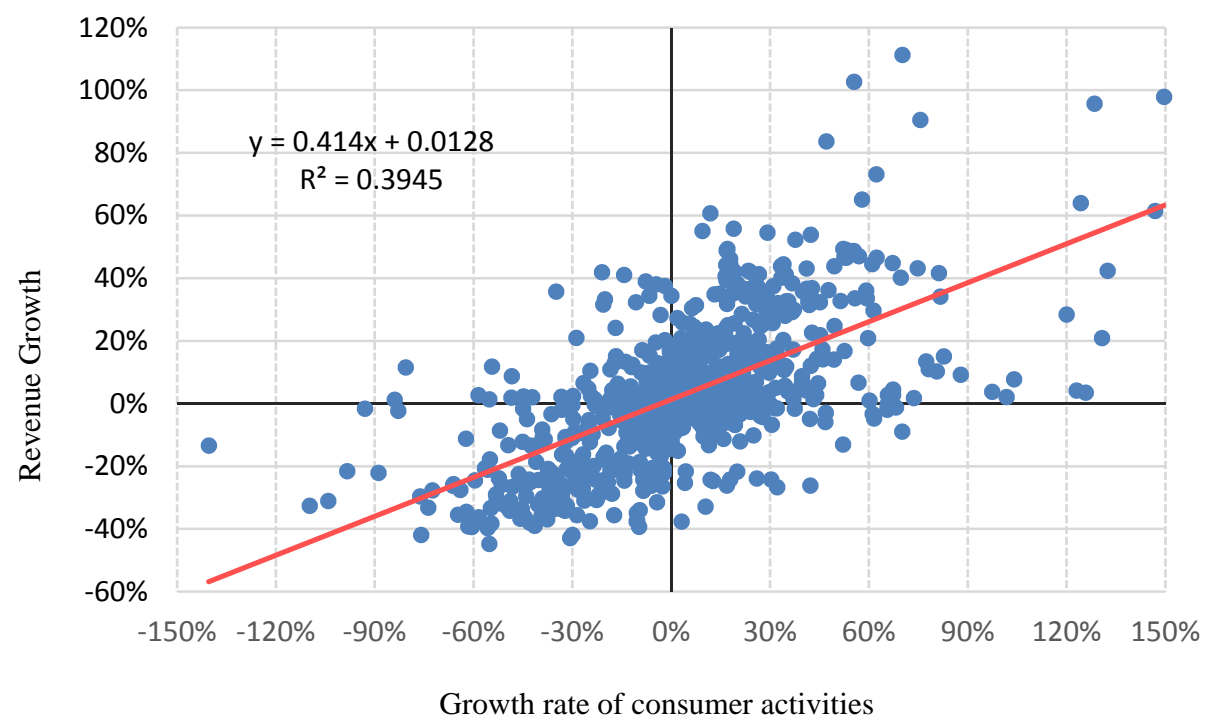

Figure 3. Revenue growth vs. consumer-activity growth. The figure scatter plots revenue growth on the growth rate of consumer activities. The vertical axis is revenue growth and the horizontal axis is the growth rate of consumer activities. The red line is the predicted value of revenue growth. The sample includes US retail firms of fiscal quarter ending between Mar 2009 and July 2014. 
Quintile 1: Buy-and-hold Return

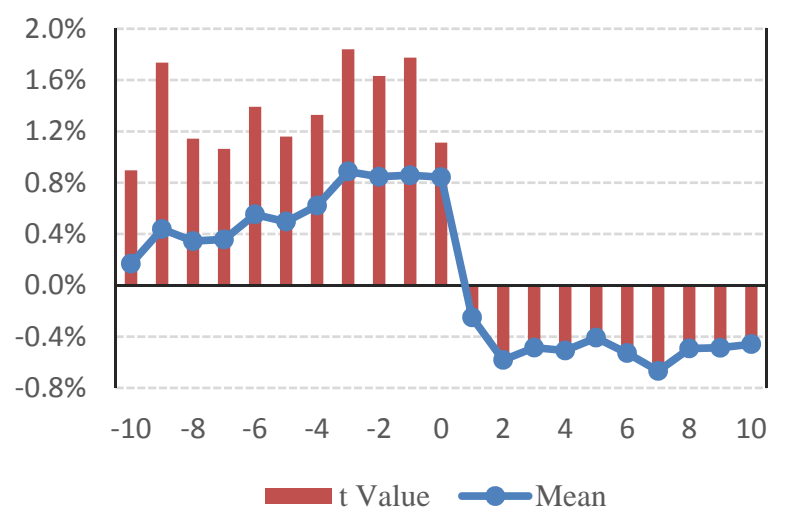

Quintile 5: Buy-and-hold Return

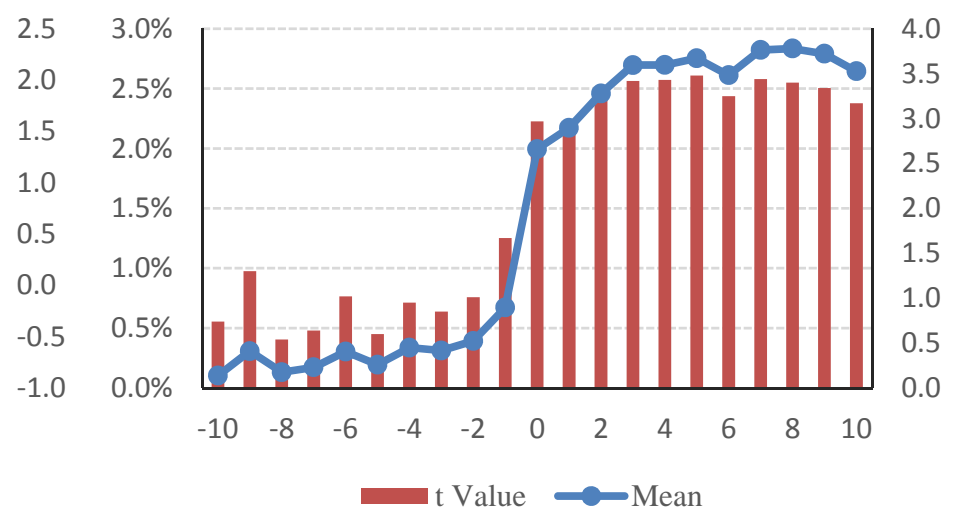

Figure 4. Excess returns around earnings announcement dates. This figure plots the average buy-and-hold returns during the event window from 10 days prior to the earnings announcement date (day 0 ) to 10 days afterward. Returns are calculated in excess of the market returns of corresponding periods. The first panel shows the average buy-and-hold return of firms in quintile 1 of within-quarter real-time corporate sales index, while the second panel shows the results of firms in quintile 5. The sample includes US retail firms of fiscal quarter ending between Mar 2009 and July 2014. 